\title{
Evolução tectono-cronológica da estrutura de interferência de Nossa Senhora de Lourdes, Faixa Sergipana, NE-Brasil
}

\author{
Juliana Finoto Bueno ${ }^{1}$, Juliano José de Souza ${ }^{2}$, \\ Mário Neto Cavalcanti Araújo ${ }^{3}$ \& Elson Paiva de Oliveira ${ }^{1}$
}

\begin{abstract}
Resumo A estrutura de interferência de Nossa Senhora de Lourdes, no domínio Macururé, Faixa Sergipana (NE-Brasil), apresenta um padrão de interferência em cogumelo resultante da evolução de sucessivos eventos de dobramentos. Estes dobramentos ocorreram pela superposição de três eventos de deformação dúctil $\left(\mathrm{D}_{1}-\mathrm{D}_{3}\right) \cdot \mathrm{D}_{1}$ é caracterizado por nappes com vergência e cavalgamentos para sul. $\mathrm{D}_{2}$ é marcado pela reativação coaxial de $\mathrm{D}_{1}$, tem um caráter transpressivo e é o principal evento colisional na faixa. Foram mapeados dois grupos de granitos alojados durante $\mathrm{D}_{2}$ : o Tonalito Camará pré a cedo- $\mathrm{D}_{2}$, com idade U-Pb SHRIMP em zircão de $628 \pm 12$ Ma, considerada a idade máxima para o início de $\mathrm{D}_{2}$. $\mathrm{O}$ outro grupo é formado por granitos sin a tardi- $\mathrm{D}_{2}$. Foram obtidas duas idades U-Pb TIMS em titanita para estes granitos; 584 \pm 10 Ma para o Granito Angico sin- $\mathrm{D}_{2}$ e $571 \pm 9 \mathrm{Ma}$ para o Granito Pedra Furada tardi- $\mathrm{D}_{2}$. Utilizando estas idades tem-se que $\mathrm{D}_{2}$ esteve em operação por pelo menos $57 \mathrm{Ma}$ na Faixa Sergipana. $\mathrm{D}_{3}$ é o último evento de deformação dúctil na estrutura de interferência, iniciando-se após 571 Ma quando a faixa experimentou um grande soerguimento em resposta a uma compressão em um regime rúptil a dúctil-rúptil. $\mathrm{D}_{4}$ encerra a orogenia neoproterozóica na região e é caracterizado pela ocorrência de estruturas rúpteis. $\mathrm{D}_{3}$ e $\mathrm{D}_{4}$ são os responsáveis pela exumação da estrutura de interferência de Nossa Senhora de Lourdes para níveis crustais mais rasos e pela atual arquitetura crustal desta região da Faixa Sergipana.
\end{abstract}

Palavras-chave: Faixa Sergipana, domínio Macururé, evolução estrutural, granitos colisionais, geocronologia $\mathrm{U}-\mathrm{Pb}$.

\begin{abstract}
Tectonic-chronologic evolution of the Nossa Senhora de Lourdes interference structure, Sergipano Belt, NE-Brazil. The Nossa Senhora de Lourdes structure is a regional dome-crescent-mushroom pattern in the Macururé domain of the Sergipano belt. It marks the interference of successive folding events that have occurred by the overprinting of three ductile deformation episodes $\left(D_{1}-D_{3}\right)$, each of them followed or crosscut by distinct granite plutons. $\mathrm{D}_{1}$ is characterized by south-verging nappes and thrust zones. $\mathrm{D}_{2}$ is marked by coaxial reactivation of $\mathrm{D}_{1}$, has a transpressive character and is the main deformation event in the belt. There are two groups of granites emplaced during $\mathrm{D}_{2}$ : the pre- to early $\mathrm{D}_{2}$ Camará tonalite with a U-Pb SHRIMP zircon age of $628 \pm 12 \mathrm{Ma}$ which is considered the maximum age for the onset of $\mathrm{D}_{2}$. The other group is the syn- to tardi$\mathrm{D}_{2}$ granites for which two U-Pb TIMS titanite ages were obtained, namely, $584 \pm 10 \mathrm{Ma}$ for the syn- $\mathrm{D}_{2}$ Angico granite and $571 \pm 9$ Ma for the tardi- $\mathrm{D}_{2}$ Pedra Furada granite. Using these ages, $\mathrm{D}_{2}$ has been in operation in the Sergipano Belt for at least 57 million years. $D_{3}$ is the last ductile deformation event in the interference structure and it took place after $571 \mathrm{Ma}$ when the belt experienced a high amount of uplift in response to compression in a brittle to ductile-brittle regime. $\mathrm{D}_{4}$ ended the Neoproterozoic orogeny in the region and is characterized by brittle structures. $\mathrm{D}_{3}$ and $\mathrm{D}_{4}$ were responsible for exhumation of the Nossa Senhora de Lourdes interference structure to shallow crustal levels and for the present crustal architecture in this part of the Sergipano belt.
\end{abstract}

Keywords: Sergipano belt, Macururé domain, structural evolution, collisional granites, U-Pb geochronology.

INTRODUÇÃO A Província Borborema (NE do Brasil) compreende a parte central de uma larga faixa orogenética Brasiliana-Pan Africana que foi formada em conseqüência da convergência e colisão dos crátons São Luís-Oeste Africano e São Francisco-Congo, no Neoproterozóico (Almeida et al. 1977, 1981). A Faixa Sergipana é uma faixa orogênica situada no sul da Província Borborema (Fig. 1) e composta pelos domínios Canindé, Poço Redondo-Marancó, Macururé, Vaza Barris e Estância
(Davison \& Santos 1989, D'el-Rey Silva 1995, Oliveira et al. 2006). Esta faixa é uma das mais significantes faixas orogênicas do Nordeste brasileiro por conter estruturas e domínios litológicos que podem ser comparados aos de orógenos fanerozóicos (Oliveira et al. 2006).

A estrutura de interferência de Nossa Senhora de Lourdes (EINSL) está localizada no domínio Macururé, no leste da Faixa Sergipana. Esta estrutura é um padrão de interferência do tipo cogumelo (tipo 2

\footnotetext{
1 - Universidade Estadual de Campinas, Departamento de Geologia e Recursos Naturais, Campinas (SP), Brasil.

E-mails: juliana.bueno@ige.unicamp.br; elson@ige.unicamp.br

2 - Yamana Gold Inc. E-mal: julsouza@yahoo.com

3 - CENPES, Petrobrás. E-mail: mario_araujo@petrobras.com.br
} 


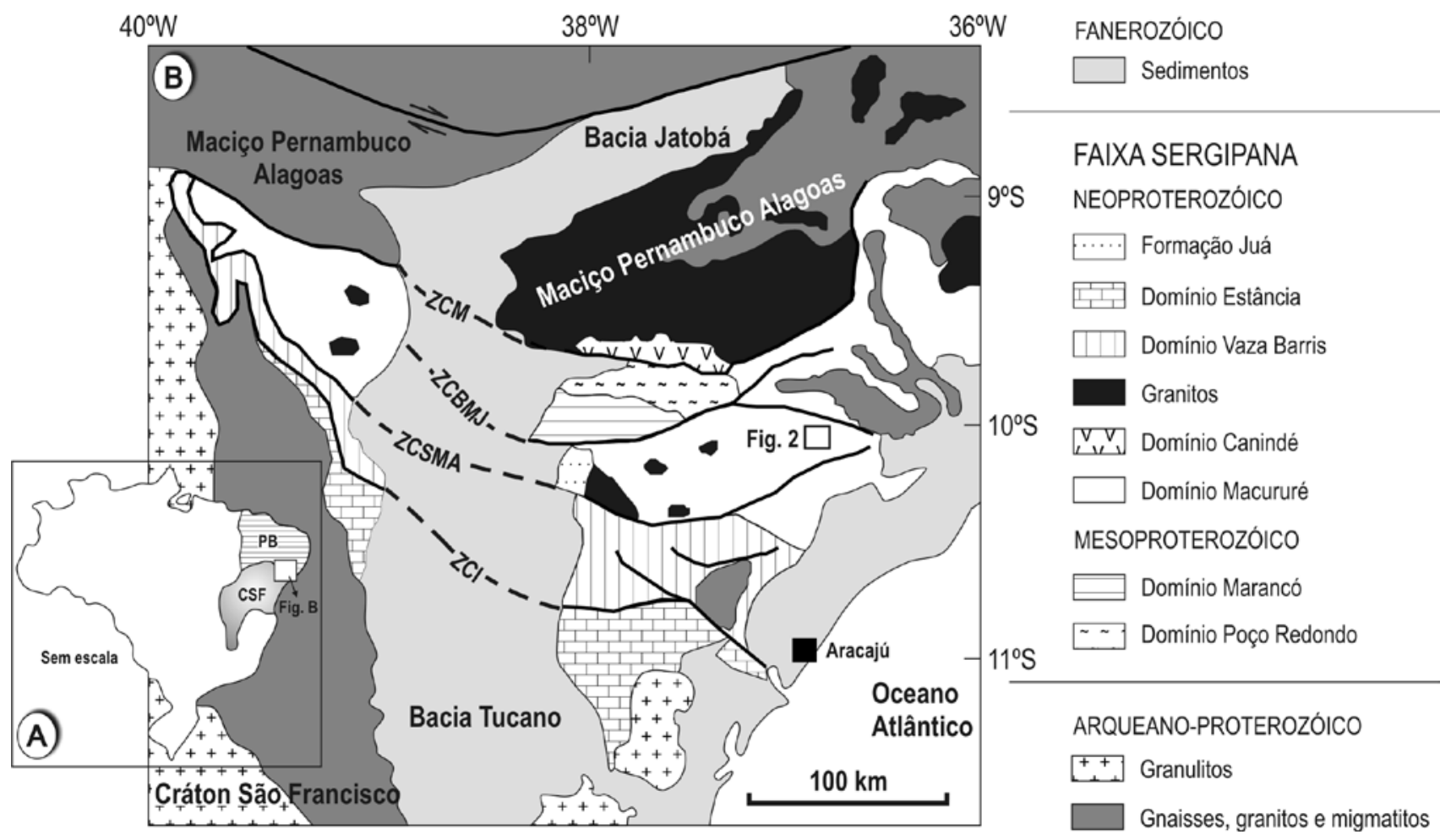

Figura 1 - A. Localização geográfica da Faixa Sergipana, $C S F=$ Cráton São Francisco e PB= Província Borborema; B. Mapa geológico da Faixa Sergipana (modificado de Oliveira et al. 2006). As siglas ZCM, ZCBMJ, CZSMA e ZCI significam zonas de cisalhamento Macururé, Belo Monte-Jeremoabo, São Miguel do Aleixo e Itaporanga, respectivamente.

de Ramsay 1967) formada pela superposição de três eventos deformacionais dúcteis registrados nas rochas supracrustais da região.

A área de ocorrência da EINSLé provavelmente a única onde estão presentes os registros de todos os eventos deformacionais ocorridos durante o Neoproterozóico no domínio Macururé e onde o registro do primeiro evento deformacional não foi totalmente obliterado pelos incrementos deformacionais posteriores. Esta área é, portanto, chave para o entendimento da evolução estrutural no domínio Macururé e por conseqüência da Faixa Sergipana.

Durante o desenvolvimento do principal evento colisional na Faixa Sergipana, foram gerados vários granitos que intrudem as rochas supracrustais da EINSL. O estabelecimento das relações estruturais destes granitos com os eventos deformacionais, juntamente com a datação destes corpos permite o estabelecimento do intervalo de duração do principal evento colisional na Faixa Sergipana.

Diversos trabalhos foram realizados na área da EINSL. Jardim de Sá et al. (1981), com base em mapeamento de Silva Filho (1977), identificaram que a superposição dos três eventos deformacionais dúcteis $\left(\mathrm{D}_{1}-\mathrm{D}_{3}\right)$, no domínio Macururé, geraram a baciacogumelo de Nossa Senhora de Lourdes, nome dado por estes autores para a EINSL. Silva (1992) e Silva et al. (1995) trabalharam numa porção da Faixa Sergipana que inclui a EINSL. Estes autores mapearam em escala 1:100.000 a EINSL e propuseram um empilhamento geométrico-estrutural para as rochas presentes nesta estrutura. Estes autores também detalharam a geologia estrutural e metamórfica da área da EINSL. Embora diversos trabalhos de mapeamentos litológico, estrutural e metamórfico tenham sido realizados na área da EINSL, ainda existe uma carência de dados geocronológicos que possam delimitar a duração dos principais eventos deformacionais na EINSL. Em áreas polideformadas é comum a utilização de granitos como marcadores espaciais e temporais da evolução da deformação, sendo que para alcançar esta finalidade é preciso estabelecer precisamente as condições estruturais e temporais de alojamento dos granitos. Na Faixa Sergipana os granitos também poderiam ser utilizados para a finalidade acima descrita, no entanto eles têm sido descritos, geralmente, como tardi a pós-colisionais (Silva 1992, Silva Filho et al. 1992, 1997, McReath et al. 1998, Long et al. 2005).

Neste trabalho são apresentadas relações de campo que comprovam a existência de pelo menos dois grupos de granitos presentes na EINSL alojados durante diferentes momentos da deformação dúctil nesta área. Também são apresentadas relações de campo entre os eventos de deformação dúctil na EINSL, perfis na escala 1:50.000 que cobrem grande parte da estrutura e dados geocronológicos nos granitos associados aos eventos deformacionais com o intuito de compreender a evolução tectônica e cronológica desta estrutura e, suas implicações para o desenvolvimento da atual arquitetura crustal nesta porção da Faixa Sergipana. 
A FAIXA SERGIPANA A Faixa Sergipana é uma faixa orogênica triangular de direção WNW-ESE (Fig. 1), situada na parte sul da Província Borborema, Nordeste do Brasil, formada provavelmente pela colisão entre o Maciço Pernambuco-Alagoas e o Cráton São Francisco durante o Neoproterozóico (Brito Neves et al., 1977, D'el-Rey Silva et al., 2007, da Silva et al., 2008). A colisão resultou na amalgamação de cinco domínios litoestruturais: Canindé, Poço Redondo-Marancó, Macururé, Vaza Barris e Estância (Davison \& Santos 1989, D'elRey Silva 1995, Carvalho 2005, Oliveira et al. 2006) os quais são limitados, respectivamente, pelas seguintes zonas de cisalhamento de norte para sul: Macururé, Belo Monte-Jeremoabo, São Miguel do Aleixo e Itaporanga (Fig. 1). Existem diversas associações petrotectônicas na Faixa Sergipana, que foram inicialmente interpretadas como características de um ambiente geossinclinal (Allard \& Hurst 1969), posteriormente como o produto da colagem neoproterozóica de terrenos tectonoestratigráficos ou microplacas (Davison \& Santos 1989), ou como um cinturão de dobramentos e cavalgamentos produzido durante a inversão de uma bacia de margem passiva mesoproterozóica (D’el-Rey Silva 1999).

São reconhecidos três eventos de deformação principais nas rochas supracrustais da Faixa Sergipana (Jardim de Sá et al. 1981, 1986, D'el-Rey Silva 1995, Araújo et al. 2003). O primeiro evento $\mathrm{D}_{1}$ é caracterizado por nappes com vergência para sul e zonas de cavalgamento ao longo das quais as rochas metassedimentares dos domínios Macururé, Vaza Barris e Estância foram deslocadas sobre o Cráton São Francisco (Jardim de Sá et al. 1992). O evento de deformação $\mathrm{D}_{2}$ é marcado pela reativação do evento compressional $\mathrm{D}_{1}$ e assume um caráter transpressivo associado com movimentos verticais que afetam a faixa inteira. $\mathrm{O}$ evento $\mathrm{D}_{3}$ encerra a deformação imposta à Faixa Sergipana e é responsável por uma série de soerguimentos que são formados em resposta a uma compressão em regime de transição dúctil-rúptil. Diversos corpos graníticos foram colocados durante a evolução destas fases de deformação; estudos de detalhe de Bueno et al. (2009 e 2005) e Bueno \& Oliveira (2007), no domínio Macururé, revelaram a existência de dois pulsos magmáticos distintos, relacionados a estas fases.

O domínio Macururé é formado principalmente por xistos pelíticos, mármores e quartzitos subordinados (Davison \& Santos 1989, Silva et al. 1995) e uma suíte de granitos colisionais (Bueno et al. 2009, Bueno \& Oliveira 2007) e foi metamorfizado em condições de fácies anfibolito (Silva 1992, Silva et al. 1995). As rochas graníticas ocupam grande parte da área do domínio Macururé em superfície, sendo que granitos róseos com enclaves biotíticos predominam e granodioritos com fenocristais de anfibólio e biotita, ricos em enclaves máficos ocorrem subordinados (Bueno et al. 2005).

A ESTRUTURA DE INTERFERÊNCIA DE NOSSA SENHORA DE LOURDES A estrutura de Nossa Senhora de Lourdes (EINSL) representa um padrão de interferência em cogumelo (tipo 2 de Ramsay 1967) com mais de $200 \mathrm{~km}^{2}$ de área aflorante, na região leste do domínio Macururé (Fig. 2), e é uma das poucas áreas que possui registros de estruturas relacionadas a todos os eventos deformacionais impostos pela evolução tectônica da Faixa Sergipana.

A partir de mapeamentos na escala 1:50.000 (Bueno inédito e Souza inédito) foram individualizadas quatro unidades metassedimentares (Xistos inferiores, Xistos intermediários, Quartzitos e Xistos superiores) que são muito semelhantes às unidades propostas por Silva (1992) e Silva et al. (1995) e que são cortadas por granitos colisionais (Fig. 2). O empilhamento proposto é estrutural e ocorreu durante a fase de deformação $\mathrm{D}_{1}$. Essa fase de deformação foi a responsável pela geração e paralelização da foliação $S_{1}$ ao acamamento primário $\mathrm{S}_{0}$, o qual foi quase que totalmente obliterado juntamente com outras estruturas primárias, dificultando assim a proposição de um empilhamento estratigráfico.

As rochas supracrustais da área são afetadas por tectônica polifásica representada por três eventos deformacionais dúcteis $\mathrm{D}_{1}-\mathrm{D}_{3}$ e um evento rúptil $\mathrm{D}_{4}$ (Fig. 3). Esta evolução aconteceu pela sucessão dos eventos acima citados, iniciada por uma tectônica de nappes com vergência para $\mathrm{SW}$, redobrados coaxialmente em $\mathrm{D}_{2}$, e transpostos por cavalgamentos $\mathrm{D}_{3}$ para SSE; posteriormente reaproveitados como transcorrências sinistrais. Essa estrutura é ressaltada regionalmente por serras de quartzitos arranjadas como dois anéis: o interno, destacado pela Serra da Melancia, e o externo, destacado pela Serra da Tabanga (Fig. 2). Destaca-se o cavalgamento registrado na base do quartzito, que constitui o anel externo, evidenciado pelo desenvolvimento de milonitos associados à fase de deformação $\mathrm{D}_{1}$.

A tectônica de nappes gerou a foliação $S_{1}$ penetrativa, tipo xistosidade, com mergulho baixo a médio $\left(10^{\circ}-40^{\circ}\right)$, transposta e/ou paralelizada a $\mathrm{S}_{0}$. Truncando a foliação $S_{1}$ são identificadas mais duas foliações, $S_{2}$ que intercepta $S_{1}$ em ângulos baixos a médios $\left(15-30^{\circ}\right)$ e a foliação $S_{3}$, menos persistente, que trunca $S_{1}$ em ângulos fortes $\left(70-85^{\circ}\right)$.

Durante a evolução dos eventos deformacionais na EINSL ocorreu metamorfismo progressivo que aumenta de grau para norte (Silva, 1992; Jardim de Sá et al. 1981; 1992; Silva et al. 1995). Davison \& Santos (1989) e Silva et al. (1995) sugerem que o metamorfismo atinge fácies anfibolito de condições de pressão intermediária e altas temperaturas. Estes autores basearam suas conclusões na ocorrência de cianita em quartzitos, ocorrência local de diatexitos e assembléias metamórficas de alta temperatura definidas por granada-biotita-estaurolitamuscovita alinhadas segundo a foliação principal $\mathrm{S}_{1}$. Silva et al. (1995) afirmaram que não há quebra metamórfica evidente entre $S_{1}$ e $S_{2}$ fato que leva a interpretação de que $\mathrm{S}_{2}$ é o auge de uma fase de deformação progressiva $D_{n}$, que evoluiu de uma foliação $S_{1}$, bem preservada nas litologias da EINSL, mas que no geral é reliquiar ou admitida por conta das relações microestruturais observadas. Foram identificados os crescimentos de granada, cianita e estaurolita sin-, tardi- e pós- $\mathrm{D}_{1}$, ${ }_{\mathrm{n}}$ as litologias da EINSL, fato que corrobora com a hipótese de Silva et al. 

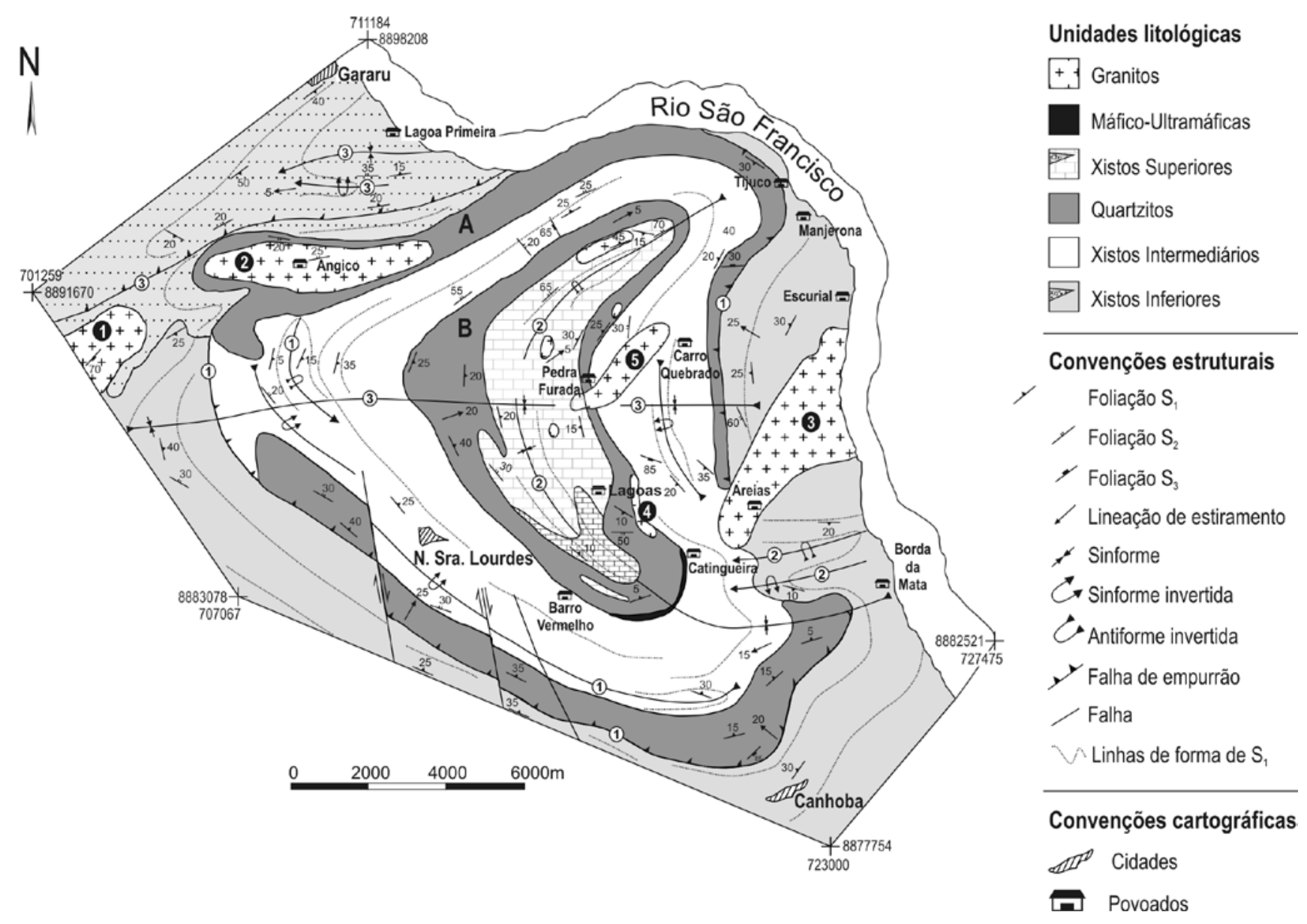

Figura 2 - Mapa geológico da estrutura de interferência de Nossa Senhora de Lourdes. As elipses preenchidas com preto estão relacionadas aos seguintes granitos:1. Tonalito Camará pré-colisional e aos granitos colisionais: 2. Granito Angico, 3. Granito Areias, 4. Granito Lagoas e 5. Granito Pedra Furada.As letras A e B significam respectivamente Anel Externo e Anel Interno da estrutura de interferência (Maiores detalhes no texto).

(1995) de que não houve quebra metamórfica entre os eventos $\mathrm{D}_{1}$ e $\mathrm{D}_{2}$. Oliveira et al. (2005) obtiveram uma idade de $570 \mathrm{Ma}$ (isócrona Sm-Nd granada-rocha total) para um granada-biotita-xisto, próximo à cidade de Gararu (Fig. 2), cuja granada tem crescimento sin- $\mathrm{D}_{2}$. Está idade é considerada como a idade do pico do metamorfimo regional na Faixa Sergipana registrado durante o evento $\mathrm{D}_{2}$ (Oliveira et al. 2005, Bueno et al. 2009).

\section{Empilhamento estrutural}

UNIDADE XISTOS INFERIORES Esta é a unidade mais externa da EINSL e é composta predominantemente por cianita-estaurolita-granada-muscovita-biotita xisto com intercalações centimétricas plano-paralelas de quartzitos e rochas cálcio-silicáticas.

O xisto é acinzentado, apresenta granulação média a grossa, textura porfiroblástica, representada por porfiroblastos de granada na região próxima à cidade de Gararu (Fig. 2) e, principalmente por cristais de cianita e estaurolita na região da cidade de Canhoba (Fig. 2). Os xistos apresentam bandamento composicional milimétrico dado por bandas quartzosas intercaladas com bandas micáceas. Em alguns afloramentos o bandamento com- posicional é dado por intercalações do xisto com rochas cálcio-silicáticas constituídas por hornblenda, granada e carbonatos. No norte da área o xisto apresenta feições de migmatização com percentuais consideráveis de fusão e inúmeras segregações quartzosas.

$\mathrm{O}$ xisto tem uma foliação principal $\mathrm{S}_{1}$, penetrativa, do tipo xistosidade marcada pela orientação de muscovita, biotita e quartzo recristalizado. Truncando a foliação $S_{1}$ são identificadas mais duas foliações, $S_{2}$ e $S_{3}$, sendo que $S_{2}$ intercepta $S_{1}$ em ângulo fraco a médio (15$30^{\circ}$ ). A foliação $S_{3}$, por sua vez, apresenta uma clivagem disjuntiva, menos persistente, que trunca $\mathrm{S}_{1}$ em ângulo forte $\left(70-85^{\circ}\right)$. As porções mais quartzosas do xisto registram freqüentemente duas lineações sincrônicas, evidenciadas principalmente por barras de quartzo. A lineação mais persistente e intensa foi caracterizada como lineação de estiramento $\mathrm{L}_{1}^{\mathrm{x}}$ e é down dip e, a segunda lineação, foi caracterizada como lineação de interseção $\mathrm{L}_{1}{ }^{0}$. Localmente, observa-se uma gradação direta entre as porções mais grossas para as mais finas, evidenciada pela recristalização de quartzo gradando para porções mais micáceas, às quais se associam a estaurolita e granada.

Entre os povoados de Catingueira e Borda da 

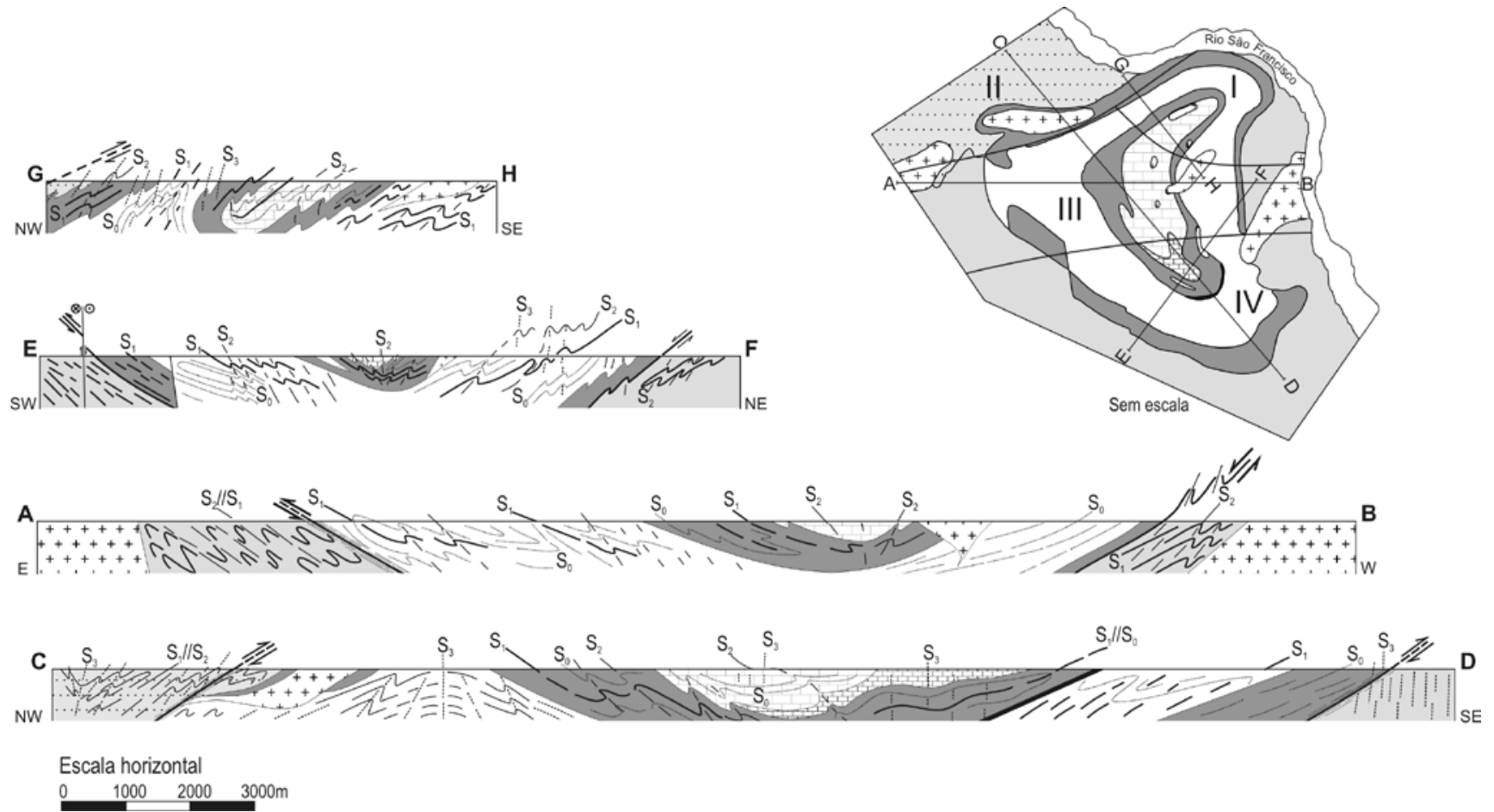

Figura 3 - Perfis estruturais para a área da estrutura de interferência de Nossa Senhora de Lourdes. À direita, mapa da estrutura de interferência de Nossa Senhora de Lourdes com a localização dos perfis e dos domínios estruturais. As legendas para as unidades litológicas são as mesmas utilizadas na figura 2.

Mata (Fig. 2) aflora uma seqüência de BIF (banded iron formation) de aproximadamente trinta metros de espessura intercalada com níveis de chert, magnetita e hematita.

O xisto é médio a grosso e é constituído por: quartzo (25-30\%), biotita (15-25\%), muscovita (10$15 \%)$, granada $(7-10 \%)$, estaurolita $(5-7 \%)$ e cianita (3-5\%). Entre os minerais acessórios destacam-se titanita, opacos (ilmenita), rutilo, turmalina e zircão, os três últimos detríticos. $\mathrm{O}$ quartzo ocorre geralmente recristalizado segundo a foliação $S_{1}$, é equigranular e apresenta contatos poligonais. Ocorrem três gerações de biotita, sendo elas microporfiroblásticas, e variam de idioblásticas a hipidioblásticas. A primeira geração tem cor parda, e é truncada pela foliação $S_{1}$, caracterizandose como pré a cedo- $\mathrm{D}_{1}$. A segunda geração de biotita é a mais abundante, tem cor castanha e se cristalizou segundo a foliação $S_{1}$, caracterizada como sin- $D_{1}$. A terceira geração não apresenta uma orientação preferencial e sobrepõe à foliação $S_{1}$, caracterizada como pós- $D_{1}$. A muscovita é sin- $\mathrm{D}_{1}$ e ocorre como microporfiroblasto e varia de idioblástica a hipidioblástica. Observam-se freqüentemente bordas de reação e feições esqueletais nos grãos de muscovita, evidenciando desequilíbrio. A granada ocorre como porfiroblasto e varia de idioblástica a hipidioblástica. Estão presentes duas gerações de granada, que apresentam característica de cristalização progressiva. A primeira geração é poiquiloblástica, sin a tardi- $\mathrm{D}_{1}$, com trilhas de inclusões de quartzo e opacos, que marcam a foliação interna $S_{i}$. A segunda geração gera o sobrecrescimento de uma borda sem inclusões na primeira geração, ou mesmo, a cristalização de ou- tro porfiroblasto idioblástico. Esse segundo momento de cristalização é tipicamente sin- $\mathrm{D}_{2}$. A estaurolita ocorre como porfiroblasto e varia de hipidioblástica a xenoblástica, com dimensões de $0,3-1 \mathrm{~cm}$. Em geral, a estaurolita é poiquiloblástica e tem inclusões de quartzo, opacos e raramente de clorita. Observa-se em alguns casos uma leve rotação destes porfiroblastos. No entanto, observa-se uma continuidade do processo de cristalização das bordas que passam a truncar a foliação $\mathrm{S}_{1}$. Logo, esses porfiroblastos de estaurolita iniciaram a cristalização sin a tardi- $\mathrm{D}_{1}$ que continuou até pós- $\mathrm{D}_{1}$. A cianita ocorre como porfiroblasto e varia de idioblástica a hipidioblástica, alcançado dimensões de até $2 \mathrm{~cm}$ em alguns locais. Elas são poiquiloblásticas, com inclusões de quartzo e opacos, e são tipicamente sin- $\mathrm{D}_{2}$.

UNIDADE XISTOS INTERMEDIÁRIOS Esta é a unidade intermediária da EINSL, posicionando-se entre os anéis externo e interno (Fig. 2). Ela é composta por dois tipos de xistos. O primeiro é um granada-muscovita-biotita xisto com estaurolita e intercalações centimétricas plano-paralelas de rochas cálcio-silicáticas. O segundo tipo é um estaurolita-muscovita xisto, normalmente intemperizado.

Os dois tipos de xistos têm uma foliação $S_{1}$ bem desenvolvida que marca a xistosidade, uma foliação $S_{2}$ que trunca $S_{1}$ em ângulos médios e uma foliação $S_{3}$ que trunca $S_{1}$ em ângulos altos. São freqüentes as segregações quartzosas paralelas à foliação $\mathrm{S}_{1} / / \mathrm{S}_{0}$, assim como veios de quartzo que variam de centimétricos a métricos.

O granada-muscovita-biotita xisto com estaurolita 
é cinza escuro, fino a médio, apresenta textura porfiroblástica dada por porfiroblastos de biotita e granada idioblástica, e em alguns locais por porfiroblastos de estaurolita. Em alguns afloramentos a granada é quase imperceptível a olho nu, evidenciando uma diferença de composição entre os afloramentos deste litotipo. Próximo ao povoado de Tijuco (Fig. 2) o afloramento deste xisto possui mais de dez metros de espessura e tem várias segregações quartzosas. A norte do povoado Pedra Furada (Fig. 2) esta rocha possui grãos de granada com até $2,0 \mathrm{~cm}$.

O estaurolita-muscovita xisto é cinza claro, médio a grosso e tem textura porfiroblástica dada por porfiroblastos de estaurolita. Os afloramentos deste litotipo estão sempre intemperizados, sendo que o solo de alteração destas rochas é bastante avermelhado, principalmente na região do povoado de Barro Vermelho.

O granada-muscovita-biotita xisto com estaurolita tem uma xistosidade marcada pela trama principal $\mathrm{S}_{1}$. Observa-se uma segunda foliação $S_{2}$ com a cristalização de biotita. Menos freqüentemente observam-se kinks em biotita e alteração da mesma para clorita, estando estes planos associados à foliação $\mathrm{S}_{3}$. Esse litotipo é constituído por quartzo (30-40\%), biotita (15-25\%), muscovita (10-15\%), granada $(5-10 \%)$, plagioclásio $(5-10 \%)$ e estaurolita (3-5\%). Entre os minerais acessórios destacamse: titanita, opacos, turmalina e rutilo, os dois últimos detríticos. O quartzo varia de hipidioblástico a xenoblástico, inequigranular, e apresenta geralmente contatos poligonais, estando recristalizado segundo foliação $S_{1}$. Normalmente, observa-se que o quartzo se concentra em níveis, marcando o bandamento composicional $\mathrm{S}_{0}$. A biotita ocorre como microporfiroblasto e varia de idioblástica a hipidioblástica. Estão presentes três gerações de biotita, a primeira (biotita 1) é parda e é obliterada pela foliação $S_{1}$, sendo caracterizada como pré a cedo- $\mathrm{D}_{1}$. A segunda geração é sin- $\mathrm{D}_{1}$ (biotita 2), é castanha e ocorre cristalizada segundo a foliação $S_{1}$. A terceira geração é sin- $D_{2}$ (biotita 3 ), menos freqüente, é castanha e ocorre no plano da foliação $\mathrm{S}_{2}$. A muscovita ocorre como microporfiroblasto e é hipidioblástica. Existem pelos menos duas gerações de muscovita. A primeira é menos freqüente e é truncada por $\mathrm{S}_{1}$, sendo pré- $\mathrm{D}_{1}$. A segunda apresenta-se cristalizada segundo a foliação $S_{1}$, sendo sin- $D_{1}$. Normalmente, os grãos de muscovita estão desestabilizados o que é evidenciado pelas bordas de reação. Os grãos de plagioclásio são geralmente xenomórficos e apresentam geminação mecânica. A granada ocorre como porfiroblasto e varia de idioblástica a hipidioblástica. Existem duas gerações de granada. A primeira é poiquiloblástica, com inclusões de quarzto e muscovita, e apresenta foliação interna $S_{i}$ quase ortogonal à $\mathrm{S}_{\mathrm{e}} / / \mathrm{S}_{1}$, sendo pré a cedo- $\mathrm{D}_{1}$. A segunda geração é geralmente bem formada, com quase ou nenhuma inclusão. Esta geração trunca a foliação $\mathrm{S}_{1}$, sendo tardi a pós- $\mathrm{D}_{1}$. Nota-se para a segunda geração o sobrecrescimento de borda com estaurolita. Os grãos de estaurolita são xenoblásticos e normalmente ocorrem como acessórios. Eles são caracterizados como tardi a pós- $\mathrm{D}_{1}$.

UNIDADE QUARTZITOS Esta unidade constitui as serras que marcam os anéis externo e interno da EINSL
(Fig. 2). Ela é composta por muscovita quartzito, muscovita-quartzo xisto e metaconglomerados.

O muscovita quartzito é cinza claro, é fino a médio e tem aspecto bandado. Em alguns afloramentos o muscovita quartzito é levemente esverdeado decorrente da presença de clorita como mineral acessório. Neste litotipo é freqüente a presença de veios de quartzo boudinados. O muscovita quartzito é fino a médio, equigranular, e é constituído por uma trama principal $\mathrm{S}_{1}$, marcada pela orientação dos grãos de quartzo recristalizados e pela orientação dos grãos de muscovita. O quartzito é constituído por quartzo (70-80\%), feldspatos $(0-5 \%)$ e muscovita (5-15\%). Entre os minerais acessórios destacam-se titanita e zircão, turmalina e opacos como minerais detríticos. Os grãos de quartzo são normalmente xenoblásticos, inequigranulares e interlobados. O quartzo apresenta extinção ondulante, migração e rotação de bordas de subgrãos. A muscovita ocorre como porfiroblasto e varia de idioblástico a hipdioblástico. Existem pelo menos duas gerações de muscovita. A primeira compõe a trama principal $S_{1}$ e é sin- $\mathrm{D}_{1}$. A segunda geração é mais discreta e ocorre associada à foliação $\mathrm{S}_{2}$, sendo sin- $\mathrm{D}_{2}$. Nas porções milonitizadas observam-se micafishes, que indicam o sentido de transporte tectônico da fase $\mathrm{D}_{1}$.

$\mathrm{O}$ muscovita-quartzo xisto tem bandamento milimétrico evidenciado por bandas quartzosas intercaladas com bandas micáceas. Freqüentemente apresenta cianita como mineral acessório. $\mathrm{O}$ muscovita-quartzo xisto, com ou sem cianita, é fino, equigranular e lepidoblástico. A trama principal $\mathrm{S}_{1}$ é marcada pelos microporfiroblastos de muscovita e por grãos de quartzo recristalizados. Esse litotipo é constituído por quartzo (50-60\%) e muscovita (35-40\%). Entre os minerais acessórios destacam-se: cianita, granada, opacos, titanita e zircão e turmalina como minerais detríticos. O quartzo varia de hipidioblástico a xenoblástico e está recristalizado segundo foliação $\mathrm{S}_{1}$. A muscovita ocorre como porfiroblasto e varia de idioblástica a hipidioblástica. Ela se encontra disposta segundo o plano de foliação $S_{1}$. A cianita ocorre como mineral acessório e é caracterizada como xenoblástica a hipidioblástica. Ela compõe a foliação $S_{1}$, apresentando característica de sin a tardi- $\mathrm{D}_{1}$.

Os metaconglomerados podem ser divididos em dois tipos. $\mathrm{O}$ primeiro é monomítico, matriz suportado, com clastos arredondados de quartzo que apresentam dimensões entre 0,5 e $1,5 \mathrm{~cm}$, e matriz constituída essencialmente por quartzo (70-85\%) e muscovita (5$10 \%$ ). Entre os minerais minoritários destacam-se zircão detrítico, opacos e titanita. O segundo tipo de conglomerado é polimítico, matriz suportado, com clastos de chert e granito, com dimensões de até $5,0 \mathrm{~cm}$, matriz recristalizada constituída por quartzo $(70-85 \%)$ e muscovita (5-10\%) e níveis de opacos com turmalina e zircão associados.

Apesar das variações em relação a granulometria dada por fácies finas, representadas pelo muscovita quartzito e o muscovita-quartzo xisto, e fácies mais grossas, representadas pelos metaconglomerados, não há evidências de gradação entre estes litotipos. 
As relações de campo (discutidas abaixo no item Relações estruturais) e petrográficas, como sigmóide de cianita em muscovita-quartzo xisto e micafishes no muscovita quartzito, indicam transporte tectônico para SW e evidenciam que as seqüências de muscovita quartzitos foram duplicadas pela tectônica de nappes, com vergência para SW, que atuou nesta porção da Faixa Sergipana. Assim, o quartzito superior, que sustenta o anel interno, representa o flanco normal de uma dobra recumbente, e o quartzito inferior, que sustenta o anel externo, representa o flanco invertido dessa mesma dobra.

UNIDADE XISTOS SUPERIORES Esta unidade está localizada no centro da EINSL e é composta por muscovita-quartzo xistos e clorita-muscovita xistos. O muscovita-quartzo xisto é fino e tem um bandamento composicional milimétrico marcado por bandas quartzosas intercaladas com bandas micáceas. O clorita-muscovita xisto é fino a médio e, em alguns locais, está intercalado com uma seqüência de rochas cálcio-silicáticas.

Nas proximidades do povoado de Pedra Furada estes litotipos são afetados pela intrusão de corpos graníticos que, durante seu alojamento, geraram inúmeros veios quartzo-feldspáticos injetados nos xistos e o crescimento de granada de cerca de $1,0 \mathrm{~cm}$ nos mesmos. Também são observados cristais de turmalina centimétricos.

O xisto é fino a médio e mostra uma trama penetrativa $S_{1}$ marcada pela orientação dos grãos de muscovita, biotita e, subordinadamente, de cianita, e uma foliação $S_{2}$ que trunca $S_{1}$ em ângulos moderados. O xisto é constituído por quartzo (20-30\%), muscovita (6-8\%), biotita (10-15\%), plagioclásio (10-15\%) e epidoto $(0-8 \%)$. Entre os minerais acessórios destacam-se granada, titanita e ilmenita. O quartzo varia de hipidioblástico a xenoblástico e está recristalizado segundo a foliação $S_{1}$. A biotita ocorre como microporfiroblastos paralelos à foliação $\mathrm{S}_{1}$, com cor marron escuro e varia de idioblástica a hipidioblástica. A muscovita apresenta duas gerações. A primeira ocorre associada à foliação $\mathrm{S}_{1}$ e está freqüentemente desestabilizada, com a presença de borda de reação. A segunda geração ocorre associada à foliação $\mathrm{S}_{2}$, e é o plano-axial das dobras $\mathrm{F}_{2}$. O plagioclásio ocorre como grãos xenomórficos e apresenta geminação mecânica.

ROCHAS MÁFICO-ULTRAMÁFICAS Este litotipo ocorre nas proximidades do povoado Catingueira e é constituído por rochas máfico-ultramáficas totalmente cloritizadas/serpentinizadas com cerca de 30 metros de espessura e paralelas a estruturação das encaixantes. Os litotipos são talco xistos, metabasaltos e metaperidotitos.

$\mathrm{O}$ metaperidotito apresenta serpentina, talco e carbonato, além de opacos. Não se observam resquícios de minerais primários. Os metabasaltos são constituídos por clorita e por produtos de alteração do plagioclásio, além de cristais idiomóficos de magnetita.

GRANITOS Os granitos que ocorrem na EINSL (Fig. 2) variam de granitos róseos a granodioritos, estes subor- dinados. Os granitos apresentam granulação fina a média, textura inequigranular e contato interlobado entre os grãos. São constituídos essencialmente por quartzo (30 a 40\%), microclina (20 a $30 \%$ ), plagioclásio (15 a $20 \%$ ), biotita (5 a $10 \%$ ), muscovita ( 1 a $5 \%$ ) e epidoto ( 0 a $5 \%$ ). Os minerais acessórios são alanita, zircão, apatita e titanita.

Relações estruturais A partição da deformação é comum em orógenos colisionais e para uma melhor visualização da evolução da EINSL, a área da sua exposição foi compartimentada em quatro domínios estruturais (I - IV), tendo como base a orientação da foliação $S_{1}$ que apresenta orientações heterogêneas ao longo da estrutura (Fig. 3).

EVENTO DE DEFORMAÇÃO $\mathrm{D}_{1} \mathrm{O}$ evento de deformação $\mathrm{D}_{1}$ é um importante evento compressivo na porção NE da Faixa Sergipana (Fig. 3). As estruturas relacionadas a este evento são evidentes em toda área da EINSL e são responsáveis pela geração de dobras recumbentes $\mathrm{F}_{1}$ regionais, dobras intrafoliais, foliação $\mathrm{S}_{1}$, lineação de estiramento $\mathrm{L}_{1}{ }^{\mathrm{X}}$ e lineação de eixo de dobra $\mathrm{L}_{1}{ }^{\mathrm{B}}$.

A foliação $S_{1}$ é penetrativa e do tipo xistosidade, de baixo a médio ângulo $\left(10 \mathrm{a} 40^{\circ}\right)$, que devido à ação dos eventos de deformação posteriores, não possui uma orientação única (Fig. 7). Esta foliação é dada pela orientação preferencial de muscovita+biotita+quartzo recristalizado \pm cianita.

As dobras $F_{1}$ geradas neste evento variam sua geometria de apertadas a isoclinais, com flancos recumbentes, eixo $\mathrm{L}_{1}^{\mathrm{B}}$ com direção NW-SE e NE-SW e mergulhos variando de 5 a $10^{\circ}$ para NW e NE respectivamente, e vergência para SW (Fig. 7).

A superfície $S_{1}$ contém uma lineação de estiramento $\mathrm{L}_{1}^{\mathrm{X}}$, com orientação predominante NE-SW e mergulhos, de aproximadamente $10^{\circ}$ para NE (Fig. 7), evidenciada pelos estiramentos de barras de quartzo $\mathrm{e}$ boudins de quartzo nos muscovita quartzitos (Fig. 4A) e de clastos nos metaconglomerados. Esta lineação em geral é down dip principalmente na parte sul da área, onde está localizada a parte frontal da EINSL, e dispõese obliquamente aos eixos das minidobras $\mathrm{F}_{1}$. Devido ao efeito de eventos de deformação superpostos, esta lineação encontra-se rotacionada em alguns afloramentos.

No sul da área, existe uma dobra recumbente $\mathrm{F}_{1}$ com amplitude quilométrica e charneira erodida (Fig. 3 ), associada à tectônica de nappes $\mathrm{D}_{1}$. Esta dobra é uma das responsáveis pela configuração da estrutura de interferência do tipo cogumelo. As evidências que demonstram a sua existência são as similaridades entre os litotipos do flanco normal e invertido, minidobras $\mathrm{F}_{1}$ parasíticas (Fig. 4B) e, localmente, gradação direta invertida. Esta dobra recumbente pode estar associada aos incrementos iniciais da tectônica de nappes $\mathrm{D}_{1}$. Num estágio subseqüente, esta dobra teve o seu flanco inferior adelgaçado, gerando milonitos basais que separam as rochas alóctones da EINSL, da seqüência autóctone sotoposta, representada pelo xisto inferior. Esse padrão de adelgaçamento do flanco invertido se repete em escala de afloramento (Fig. 4C) e lâmina delgada. Os indicadores cinemáticos, tais como minidobras $\mathrm{F}_{1} \mathrm{e}$ 

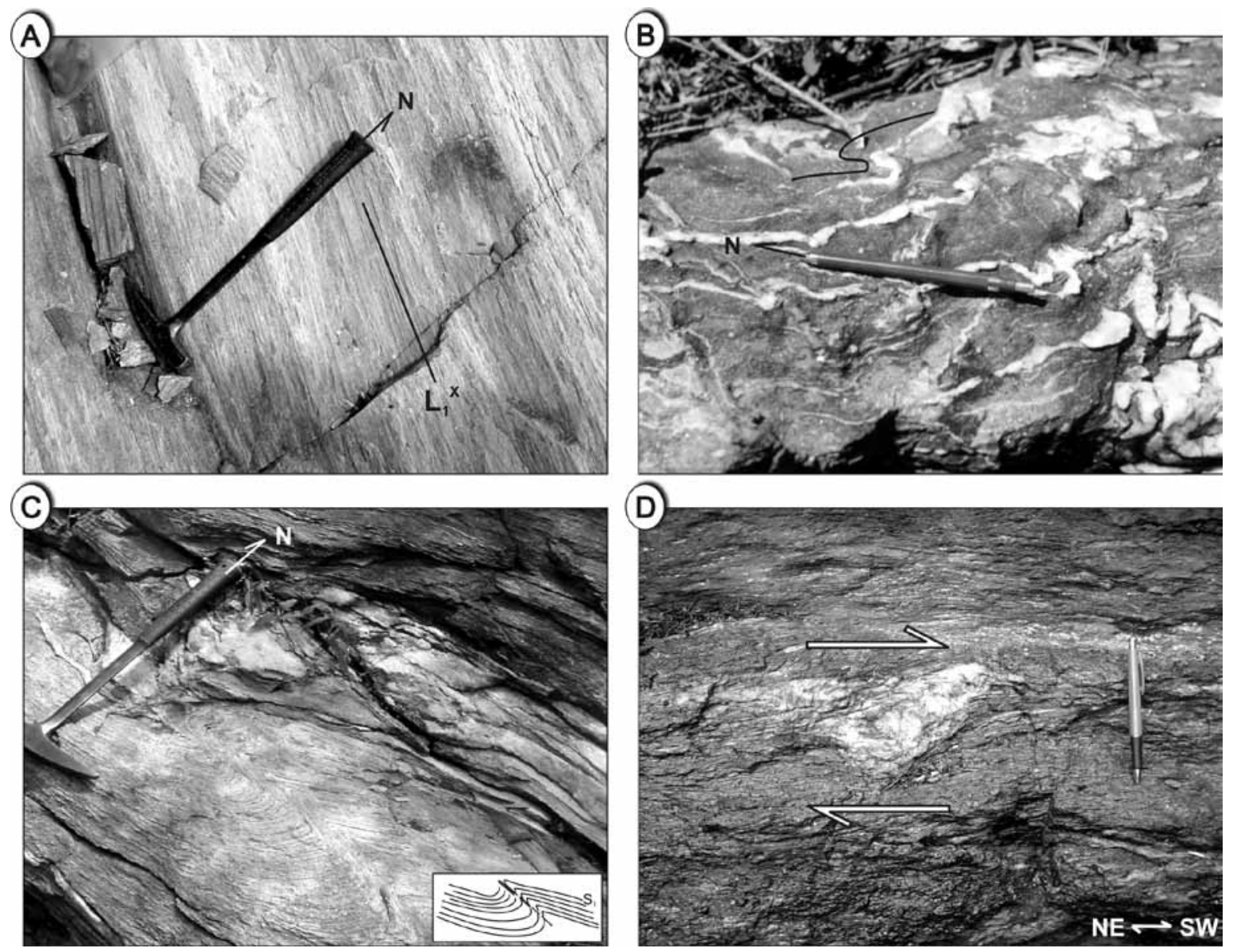

Figura 4 - Aspectos estruturais do evento de deformação $D_{I}$. A. Lineação de estiramento $L_{1}^{X}$ em muscovita quartzito; $B$. Minidobra $F$, indicando flanco normal; $C$. Adelgaçamento do flanco invertido de uma dobra recumbente $F_{1}$ em quartzito e D. Sigmóide em veio de quartzo indicando transporte para $S W$.

sigmóides em veios de quartzo, encontrados nos quartzitos do anel inferior, indicam transporte tectônico para $\mathrm{SW}$ ao longo de zonas miloníticas $\mathrm{D}_{1}$ (Fig. 4D).

EVENTO DE DEFORMAÇÃO $\mathrm{D}_{2} \quad \mathrm{O}$ evento $\mathrm{D}_{2}$ é coaxial e ocorre em continuidade cinemática e metamórfica com o evento $D_{1}$. É marcado por uma foliação $\mathrm{S}_{2}$ dada pela orientação preferencial de biotita + granada \pm quartzo recristalizado, dobras e minidobras $\mathrm{F}_{2}$ que variam de fechadas a abertas, e uma lineação de estiramento $\mathrm{L}_{2}{ }^{\mathrm{X}}$.

A foliação $\mathrm{S}_{2}$ tem mergulhos moderados $(20 \mathrm{a}$ $40^{\circ}$ ) para NW-SE (Fig. 7), principalmente na parte norte da área. Já na parte sudoeste da área, o evento $\mathrm{D}_{2}$ gera uma foliação penetrativa $S_{2}$ com mergulhos moderados (em torno de $20^{\circ}$ ) para NW dada $\mathrm{S}_{2}$ trunca $\mathrm{S}_{1}$ com ângulos de 10 a $20^{\circ}$.

As dobras deste evento são assimétricas (Fig. 5A), variando de fechadas a apertadas e chegam a apresentar comprimentos de onda da ordem de $2 \mathrm{~km}$. Os eixos de dobra $\mathrm{L}_{2}{ }^{\mathrm{B}}$ (Fig. 5B) possuem orientação preferencial NE-SW e subordinada NW-SE com mergulhos variando de 5 a $10^{\circ}$ para NW e NE, respectivamente. Na região do povoado de Borda da Mata (Fig. 2) há uma sucessão de sinformes e antiformes com eixo ENE-WSW e mergulho em torno de $5^{\circ}$ para SW.
A lineação de estiramento $\mathrm{L}_{2} \mathrm{x}$, evidenciada através do estiramento de barras de quartzo e atribuída a este evento, possui direção predominante NE-SW e mergulhos variando de 5 a $10^{\circ}$ (Fig. $5 \mathrm{C}$ ).

A superposição de $\mathrm{D}_{2}$ em relação a $\mathrm{D}_{1}$ gera interferência de $\mathrm{F}_{1} \mathrm{xF}_{2}$ com padrão coaxial (Figs. $5 \mathrm{~B}$ e D) a rotação da lineaçã̃o de estiramento $\mathrm{L}_{1}^{\mathrm{x}}$ (Fig. $5 \mathrm{C}$ ).

EVENTO DE DEFORMAÇÃO $\mathrm{D}_{3}$ O evento de deformação $\mathrm{D}_{3}$ é oblíquo aos eventos anteriores com direção de maior encurtamento N-S, gerando cavalgamentos para SSE (Fig. 3). As estruturas correlacionadas a este evento são dobras abertas, crenulações com orientação E-W nos xistos e clivagens disjuntivas nos quartzitos; estas feições são indicativas de que este evento possui características de um regime dúctil-rúptil, já em um nível crustal mais raso. Este evento está associado às zonas de cisalhamento regional $\mathrm{D}_{3}$ Belo Monte Jeremoabo e São Miguel do Aleixo, a norte e sul da área de estudos, respectivamente (Fig. 1).

As dobras $\mathrm{F}_{3}$ são abertas (Fig. 6A) e a foliação de plano axial $\mathrm{S}_{3}$ das mesmas tem orientação preferencial E-W com mergulhos elevados, da ordem de $50^{\circ}$ a $70^{\circ}$, podendo chegar a ser subverticais dentro da estruturas de interferência (Fig. 6B). A foliação $S_{3}$ não é pe- 

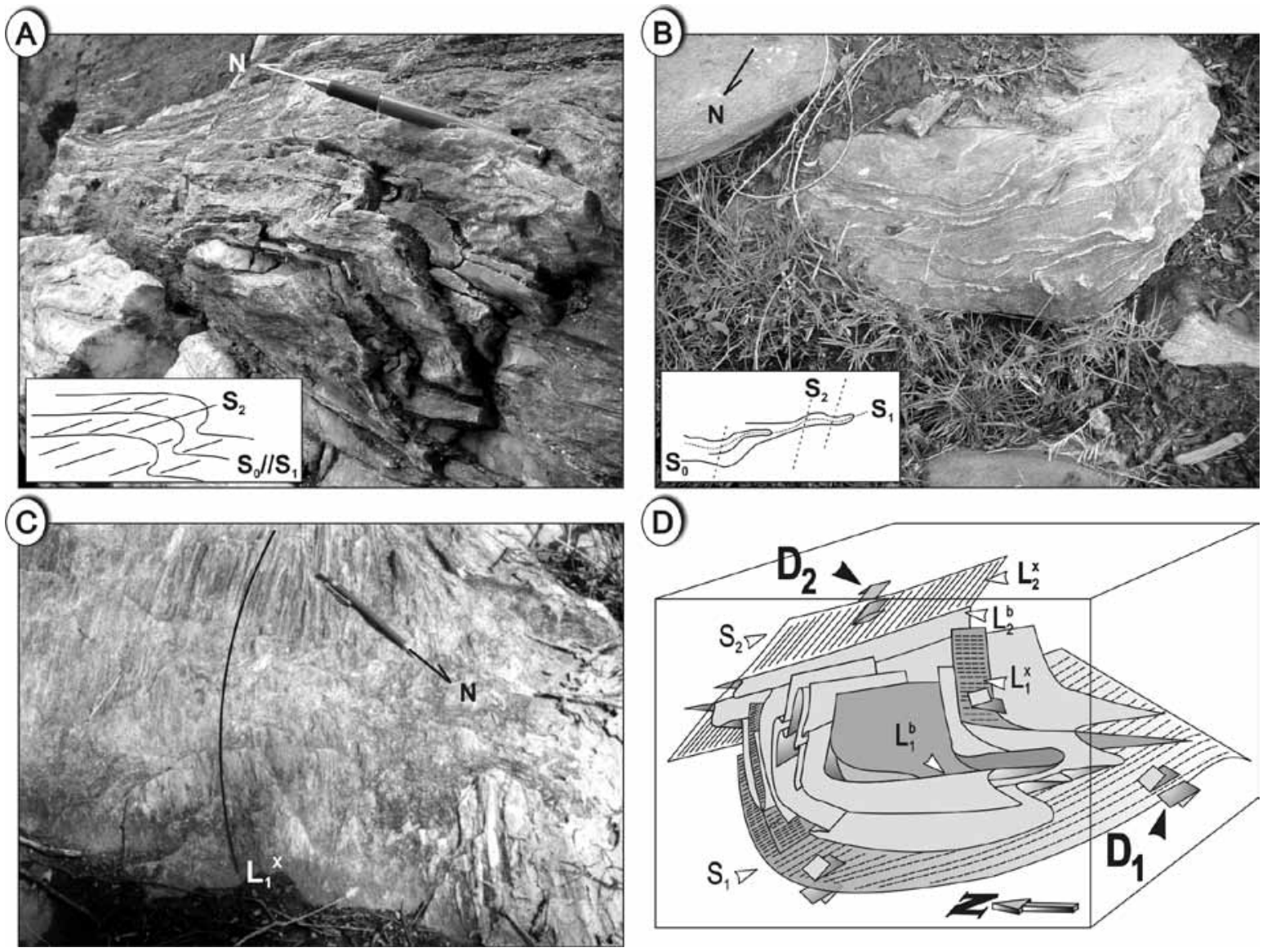

Figura 5 - Aspectos estruturais do evento de deformação $D_{2}$. A. Dobra $F_{2}$ assimétrica em muscovita quartzito; B. Padrão de interferência coaxial $F_{1} x F_{2}$ em muscovita-quartzo xisto; $C$. Lineação de estiramento $L_{1}^{X}$ em muscovita quartzito rotacionada em $D$, D. Bloco diagrama ilustrando as relações cronológicas e cinemáticas durante a superposição de $D_{1}$ com $D_{2}$.
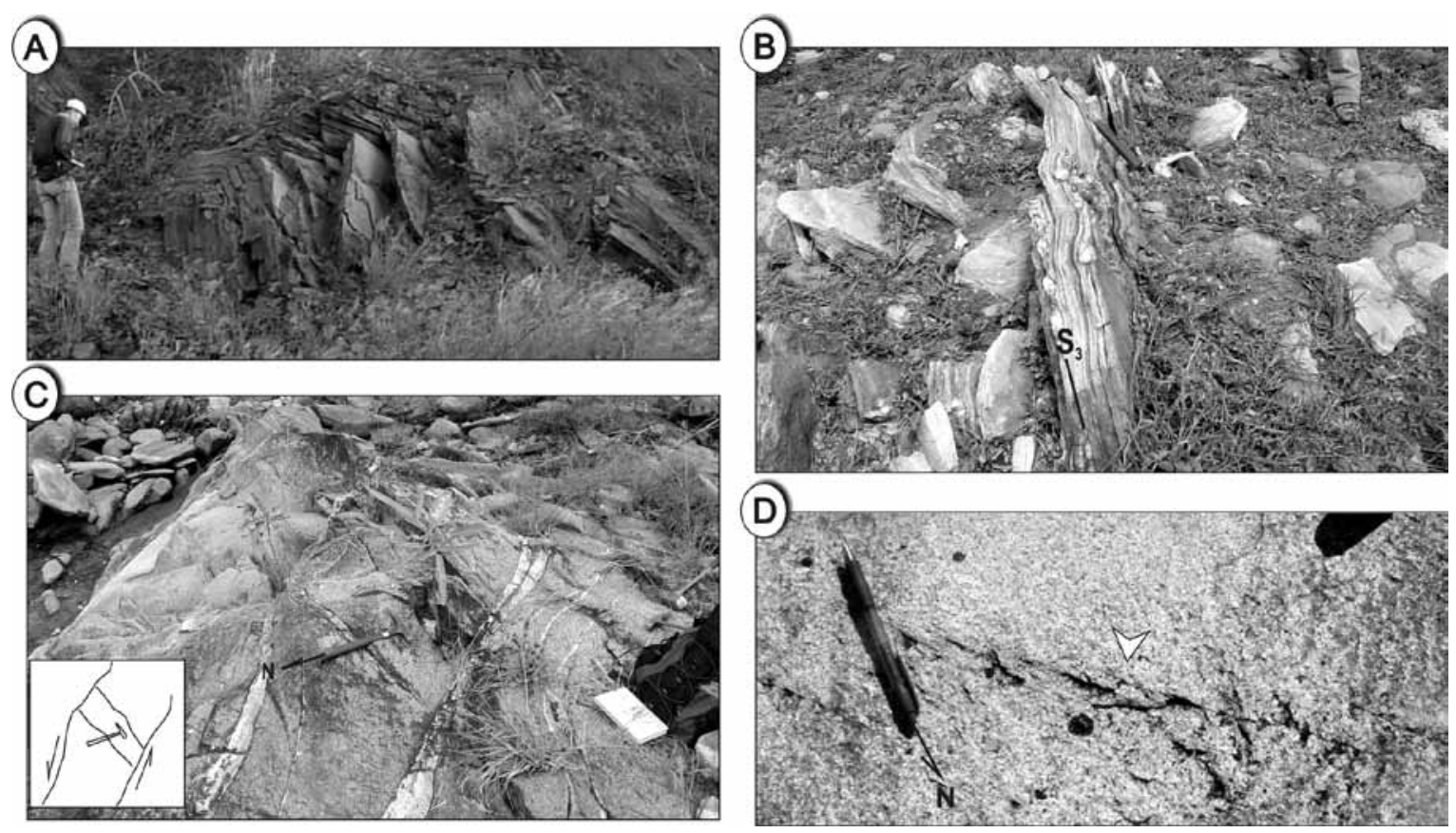

Figura 6 - Aspectos estruturais do evento de deformação $D_{3}$. A. Dobras em kink com amplitude de onda $\approx 2 \mathrm{~m} ; B$. Foliação $S_{3}$ verticalizada em muscovita quartzito, C. Tonalito Camará com zona de cisalhamento e juntas de Riedel indicando cinemática sinistral. Aspectos estruturais do evento de deformação $D_{4}$. D. Juntas extensionais em granito. 
Setor 1
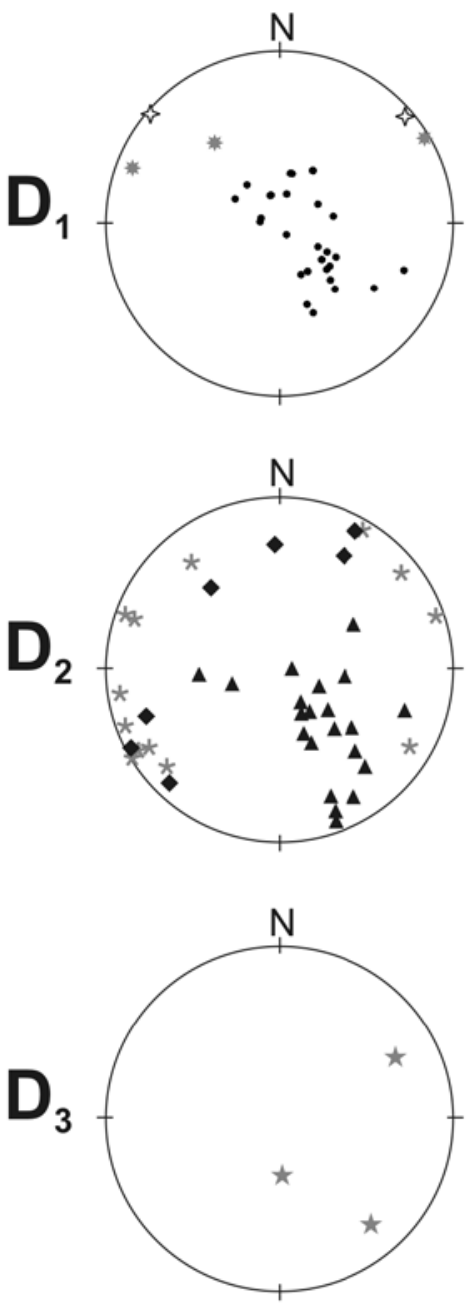

S, pólo
Setor 2
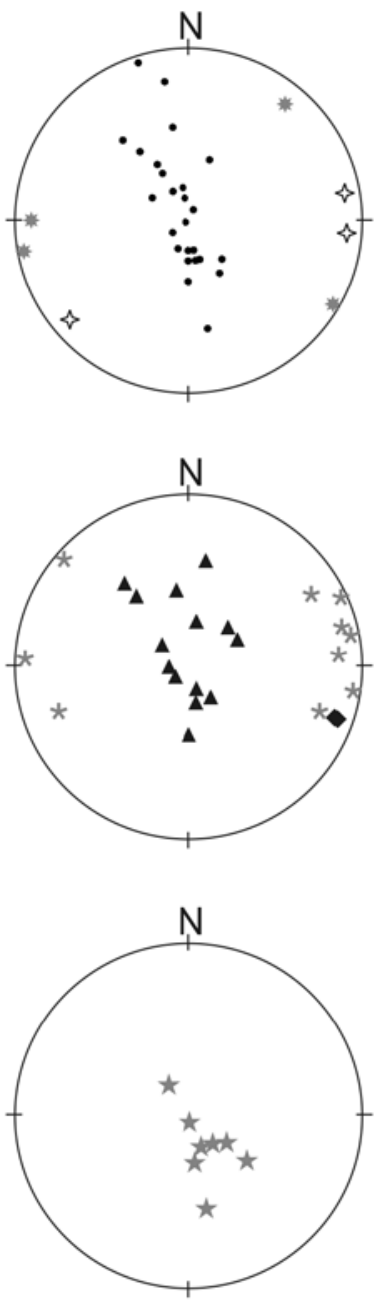

$\star \mathrm{S}_{3}$ pólo
Setor 3
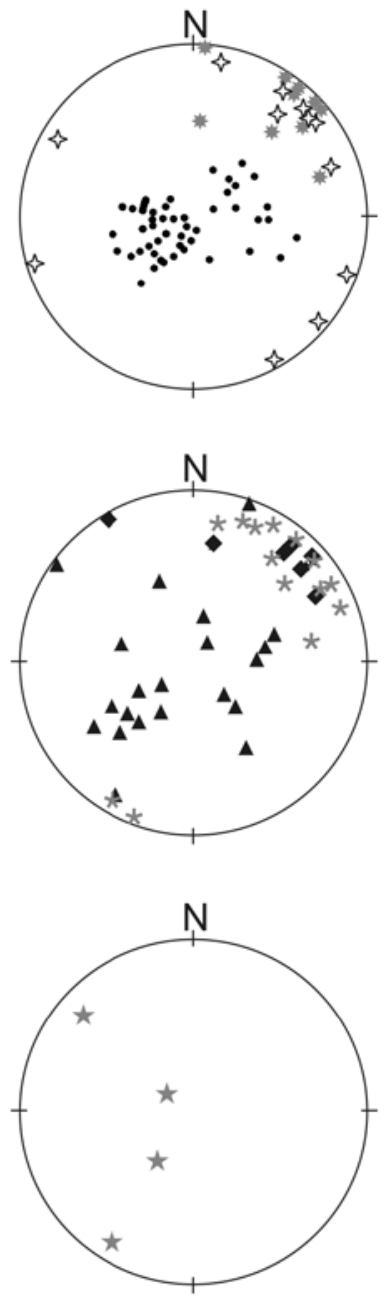

$\square \mathrm{L}_{3}{ }^{\mathrm{x}}$

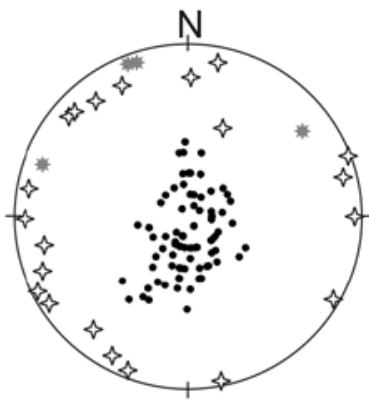

Setor 4
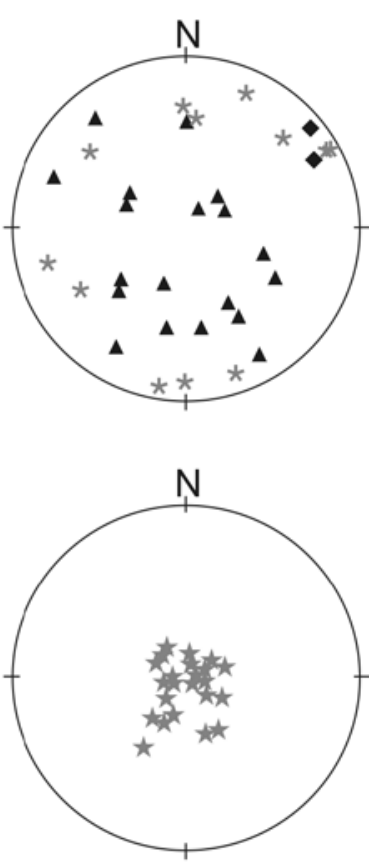

$* \mathrm{~L}_{2}^{\mathrm{B}} \quad+\mathrm{L}_{3}{ }^{\mathrm{B}}$

Figura 7 - Estereogramas para as estruturas planares e lineares desenvolvidas nos quatro setores da EINSL. Maiores detalhes no texto.

netrativa e nem homogênea ao longo da área mapeada.

Os cavalgamentos $\mathrm{D}_{3}$ são responsáveis pelo redobramento das estruturas planares relacionadas aos eventos anteriores, gerando um sinforme aberto $\mathrm{F}_{3}$ com comprimento de onda de $12 \mathrm{~km}$ aproximadamente. $\mathrm{Na}$ região do povoado de Lagoa Primeira (Fig. 2) observase uma seqüência de sinformes e antiformes com eixo $\mathrm{L}_{3}{ }^{\mathrm{B}} \mathrm{NE}-\mathrm{SW}$ mergulhando $5^{\circ}$ para NE. A superposição de $\mathrm{D}_{3}$ com $\mathrm{D}_{2}+\mathrm{D}_{1}$ gera a estrutura de interferência de Nossa Senhora de Lourdes.

Na parte NW da área a progressão dos cavalgamentos para SSE em $\mathrm{D}_{3}$ gera transcorrências sinistrais (Fig. 6C) que afetam o Tonalito Camará (Fig. 2), um dos corpos graníticos detalhados neste estudo.

A parte sudoeste da área não é afetada pelo evento $D_{3}$. Esta área foi afetada principalmente pelo evento $\mathrm{D}_{2}$ que gerou uma foliação penetrativa de mergulhos moderados (em torno de $20^{\circ}$ ) para NW.

As microestruturas $\mathrm{D}_{3}$ são pouco desenvolvidas, ocorrendo principalmente como planos de fraturas e pla- nos de kink perpendiculares à foliação $S_{1}$. Nota-se nestes planos a ocorrência de clorita evidenciando reações de retro-metamorfismo na biotita, estaurolita e granada.

EVENTO DE DEFORMAÇÃO $\mathrm{D}_{4}$ Este evento é caracterizado pela ocorrência de estruturas rúpteis indicando transição de domínios dúctil-rúptil, já em um nível crustal raso.

As estruturas frágeis encontradas na área são fraturas, falhas normais e falhas transcorrentes dextrais na parte sul da área (Fig. 3), que afetam os quartzitos do anel externo da estrutura de interferência de Nossa Senhora de Lourdes. Também são geradas juntas extensionais nos granitos (Fig. 6D).

A tabela 1 mostra uma síntese das observações estruturais na área da EINSL.

ALOJAMENTO DOS GRANITOS NA ÁREA DA

EINSL O domínio Macururé é intrudido por um volumoso conjunto de corpos graníticos cuja caracterização 
Tabela 1 - Síntese das correlações entre as estruturas observadas na área estudada e os eventos de deformação.

\begin{tabular}{|c|c|c|c|c|}
\hline Evento & Foliação & Lineação & Dobras & Estilo tectônico \\
\hline $\mathrm{D}_{1}$ & $\begin{array}{c}\text { Penetrativa, do tipo xistosidade, } \\
\text { de baixo a médio ângulo, sem } \\
\text { direção única }\end{array}$ & $\begin{array}{l}\text { Down dip a oblíqua, } \\
\text { mergulho predominante } \\
\text { para NE e SW }\end{array}$ & $\begin{array}{l}\text { Dobras isoclinais } \\
\text { recumbentes com } \\
\text { vergência para SW }\end{array}$ & $\begin{array}{l}\text { Cavalgamentos e } \\
\text { tectônica de nappes }\end{array}$ \\
\hline $\mathrm{D}_{2}$ & $\begin{array}{l}\text { Penetrativa na parte SSW da } \\
\text { área com mergulhos moderados } \\
\text { e, incipiente nas demais partes }\end{array}$ & $\begin{array}{l}\text { Estiramento, mergulho } \\
\text { predominante para NE } \\
\text { e SW }\end{array}$ & $\begin{array}{l}\text { Assimétricas variando de } \\
\text { fechadas a apertadas }\end{array}$ & $\begin{array}{l}\text { Redobramento coaxial } \\
\text { das nappes } \mathrm{D}_{1}\end{array}$ \\
\hline $\mathrm{D}_{3}$ & $\begin{array}{c}\text { Incipiente, subvertical na área } \\
\text { da EINSL }\end{array}$ & ----- & $\begin{array}{l}\text { Abertas, eixo sub- } \\
\text { horizontal com direção } \\
\text { E-W }\end{array}$ & $\begin{array}{l}\text { Redobramento das } \\
\text { dobras } \mathrm{F}_{2} \text {, rampas de } \\
\text { cavalgamentos com } \\
\text { mergulho subvertical, } \\
\text { evoluindo para } \\
\text { transcorrências sinistrais }\end{array}$ \\
\hline $\mathrm{D}_{4}$ & Rúptil & ----- & ----- & $\begin{array}{l}\text { Tectônica rúptil com } \\
\text { estruturas rúpteis a } \\
\text { dúctil-rúpteis }\end{array}$ \\
\hline
\end{tabular}

quanto ao contexto de ambiência tectônica e correlação com a história cinemática da Faixa Sergipana ainda é pouco compreendida. A evolução estrutural na EINSL é de extrema importância porque é nesta área onde são observados todos os eventos deformacionais no domínio Macururé e a intrusão de granitos associados a alguns destes eventos. A correlação dos granitos com os eventos deformacionais, juntamente com a datação absoluta destes plutons, permite o estabelecimento das relações temporais entre eventos orogênicos em regiões polideformadas. $\mathrm{Na}$ área de estudos foram individualizados dois tipos cronológicos de granitos: (i) granitos sin a tardi- $\mathrm{D}_{2}$ e (ii) granitos pré a cedo- $\mathrm{D}_{2}$ (Bueno et al. 2009) que serão detalhados a seguir. A datação $\mathrm{U}-\mathrm{Pb}$ dos granitos do domínio Macururé pode fornecer informações sobre o tempo de duração do principal evento colisional na Faixa Sergipana, o evento $D_{2}$.

Neste trabalho nos referimos ao termo granito colisional como sendo aquele cronologicamente associado ao evento de maior encurtamento crustal na Faixa Sergipana, ou seja, $\mathrm{D}_{2}$ (Jardim de Sá et al. 1986, Araújo et al. 2003). Portanto os granitos colisionais são aqueles de colocação sin a tardi- $\mathrm{D}_{2}$ e os granitos pré a cedo- $\mathrm{D}_{2}$ são aqui denominados de granitos pré-colisionais.

Em relação aos eventos deformacionais, os granitos da EINSL foram caracterizados de acordo com os seguintes critérios: (i) granitos pré a cedo$\mathrm{D}_{2}$ é um granitóide alojado antes ou próximo do início do evento $\mathrm{D}_{2}$; ele mostra uma estrutura de deformação em estado sólido (foliação ou lineação) correspondente ao evento $\mathrm{D}_{2}$, (ii) granitos sin- $\mathrm{D}_{2}$ é um pluton que absorve parte ou toda deformação $\mathrm{D}_{2}$ e preserva estruturas magmáticas que são paralelas às estruturas das rochas encaixantes, (iii) granitos pós- $\mathrm{D}_{2}$ é o granitóide que corta as estruturas $\mathrm{D}_{2}$ das rochas encaixantes e não apresentam estruturas planares ou lineares relacionadas a $\mathrm{D}_{2}$.
Granitos pré a cedo- $D_{2}$ Este litotipo é um biotitahornblenda tonalito constituído por quartzo, biotita, hornblenda, plagioclásio e epidoto. Alanita com núcleo de epidoto, titanita e apatita são os principais minerais acessórios. O representante deste grupo é o Tonalito Camará (Fig. 2) que ocorre na parte oeste da EINSL como lentes concordantes com a foliação $\mathrm{S}_{2}$ nos xistos encaixantes. No contato com os xistos, o tonalito desenvolve uma foliação $S_{2}$ penetrativa e paralela à $S_{2}$ do xisto. Este corpo não apresenta estruturas de fluxo magmático preservadas. $\mathrm{O}$ tonalito foi afetado em diferentes graus pelo evento de deformação $\mathrm{D}_{3}$. Em algumas porções do pluton sua foliação $S_{2}$ apresenta variações nas atitudes que geram dobras suaves $\mathrm{F}_{3}$. Em direção ao norte o tonalito mostra aspecto milonítico possivelmente associado a uma zona de cisalhamento subordinada transcorrente sinistral $\mathrm{D}_{3}$ presente na porção noroeste da sua área de exposição. Indicadores cinemáticos, como zonas de cisalhamento em escala de afloramento e juntas de Riedel associados a $\mathrm{D}_{3}$, bem como análises em eixo-c de quartzo em amostras deste corpo, indicam cinemática sinistral condizente com a cinemática observada para a zona de cisalhamento Belo Monte-Jeremoabo que ocorre a norte do pluton (Fig. 1).

Este corpo contém muitos xenólitos do xisto encaixante com uma foliação prévia $\left(\mathrm{S}_{1}\right)$ muito penetrativa (Fig. 8A). Esta informação associada ao fato do Tonalito Camará ter registros de estruturas planares associadas aos eventos $\mathrm{D}_{2}$ e $\mathrm{D}_{3}$ são suficientes para atribuir uma colocação pré a cedo- $\mathrm{D}_{2}$ para este corpo.

No Tonalito Camará, o quartzo está microgranulado com extinção ondulante forte, borda de subgrão e, algumas vezes, recristalizado em fitas paralelas à foliação $\mathrm{S}_{2}$ (Fig. 8B). O plagioclásio apresenta geminação mecấnica, extinção ondulante forte, borda de subgrão, kinks e fraturas. O plagioclásio também apresenta cauda de recristalização e sombras de pressão com recristalização de quartzo. 

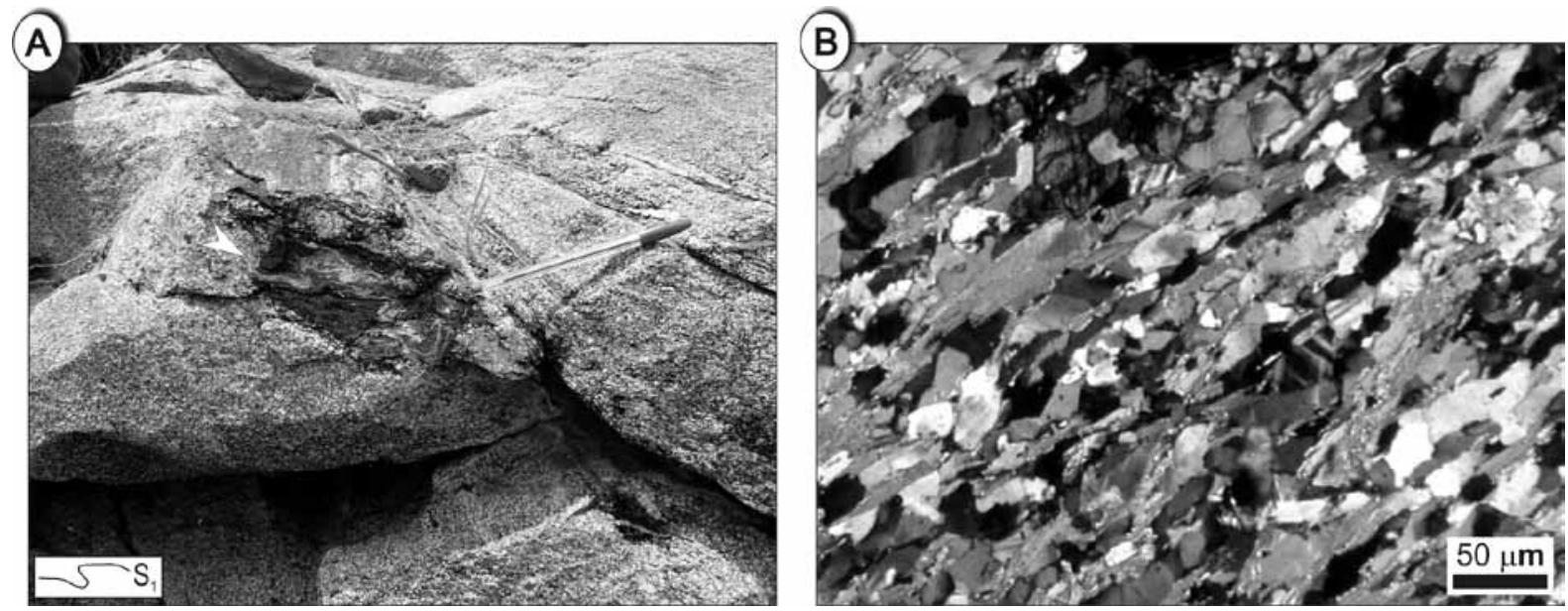

Figura 8 - Tonalito Câmara mostrando: A. Xenólito do xisto encaixante com uma foliação ( $\left.S_{\perp}\right)$ prévia; B. Foliação $S_{2}$ marcada por palhetas de biotita e fitas de quartzo.

Granitos sin- a tardi- $\mathrm{D}_{2}$ Os granitos sin a tardi- $\mathrm{D}_{2}$ (ex. Granitos Angico, Areias, Lagoas e Pedra Furada) ocorrem na EINSL como corpos alongados E-W a NESW (Fig. 2).

Eles têm composição principalmente granítica e subordinadamente granodiorítica. Estes granitos são finos a médios, têm textura seriada e contato interlobado entre os grãos. São constituídos essencialmente por quartzo (30 a 40\%), microclina (20 a 30\%), plagioclásio (15 a $20 \%)$, biotita (5 a 10\%), muscovita (1 a 5\%) e epidoto $(0$ a $5 \%)$. Os minerais acessórios são alanita, zircão, apatita e titanita.

Os granitos sin a tardi- $\mathrm{D}_{2}$ são corpos tabulares que preservam feições magmáticas como bandamento magmático e abundância de estruturas schlieren e enclaves máficos alinhados segundo a direção da foliação $S_{2}$ das rochas encaixantes. Esses granitos são injetados como folhas (Fig. 9A) no plano axial de dobras $\mathrm{F}_{2}$ dos xistos encaixantes (Fig. 9B) e nas charneiras destas dobras originando plutons de maior extensão (Fig. 9C), como o Granito Itabi que ocorre a sul da área da EINSL. Em alguns casos, os granitos são alojados truncando a foliação $\mathrm{S}_{2}$ dos xistos (Fig. 9D). Indicadores cinemáticos mesoscópicos são ausentes nestes tipos de rocha.

Os granitos apresentam como trama principal uma foliação magmática $\mathrm{S}_{\mathrm{M}}$, na borda dos corpos, dada pelo alinhamento planar de palhetas de biotita com orientação paralela à foliação $S_{2}$ do xisto encaixante. No centro das intrusões quase não há registro de tramas deformacionais penetrativas. Apesar dos granitos sin a tardi- $\mathrm{D}_{2}$ não apresentarem claramente uma foliação tectônica em escala mesoscópica, em escala microscópica estes corpos apresentam evidências de deformação dúctil em estado sólido, tais como deformação intracristalina dada pela extinção ondulante forte em grãos de quartzo e biotita, recristalização dinâmica mostrada pela recristalização por rotação de subgrãos de quartzo e feldspato e recristalização por migração de borda de grãos de quartzo e feldspato
(Fig. 10A), e recristalização estática de grãos de quartzo (Fig. 10B). Os granitos também apresentam evidências de deformação em estado rúptil como fraturas em grãos de quartzo e plagioclásio. A recristalização dinâmica de quartzo e feldspato indica que os granitos foram deformados no estado sólido em temperaturas da ordem de 400 a $550^{\circ} \mathrm{C}$ (Passchier \& Trouw 2005) que são condizentes com as condições metamórficas de fácies anfibolito proposta para o domínio Macururé durante o evento $\mathrm{D}_{2}$ (Davison \& Santos 1989, Silva et al. 1995, Oliveira et al. 2006).

GEOCRONOLOGIA U-PB Bueno et al. (2009) obtiveram três idades $\mathrm{U}-\mathrm{Pb}$ para os granitos intrusivos nas rochas da EINSL. Uma idade U-Pb (SHRIMP) em zircão foi obtida para um pluton pré a cedo- $\mathrm{D}_{2}$, o Tonalito Camará. As outras duas idades foram obtidas em grãos de titanita por U-Pb (TIMS) para o Granito Angico sin- $\mathrm{D}_{2}$ e Granito Pedra Furada tardi- $\mathrm{D}_{2}$. Nestes dois últimos grupos de granitos os grãos de zircão encontrados eram poucos e estavam metamitizados, intensamente fraturados e com bordas de sobrecrescimento. Por este motivo Bueno et al. (2009) optaram por fazer as análises em grãos de titanita.

O Tonalito Camará é uma intrusão pré a cedo- $\mathrm{D}_{2}$ nos micaxistos do domínio Macururé. O tonalito mostra uma foliação $S_{2}$ penetrativa e paralela à foliação $S_{2}$ dos xistos. Grãos de zircão deste corpo produziram uma idade $\mathrm{U}-\mathrm{Pb}$ de $628 \pm 12 \mathrm{Ma}$ (Bueno et al. 2009) que é interpretada como a idade de cristalização do tonalito e a idade máxima estimada para o início do evento $\mathrm{D}_{2}$.

Foram analisados grãos de titanita do Granito Angico que proveram uma idade U-Pb de $584 \pm 10$ Ma. Para o Granito Pedra Furada foram obtidas análises U-Pb em titanita que geraram uma idade de $571 \pm 9$ Ma. O Granito Pedra Furada é um corpo de alojamento tardi-D $\mathrm{D}_{2}$ na EINSL; este granito corta a foliação $\mathrm{S}_{2}$ dos micaxistos e sua idade é interpretada como idade mínima para o término do evento $D_{2}$. 

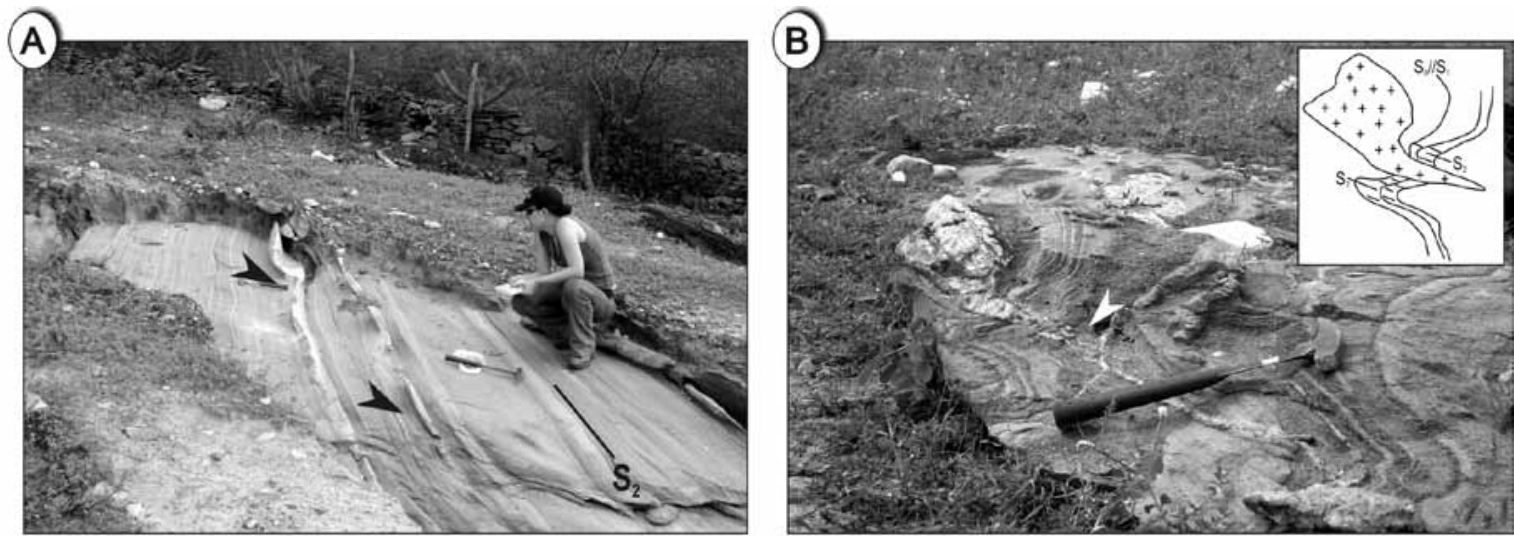

(C)
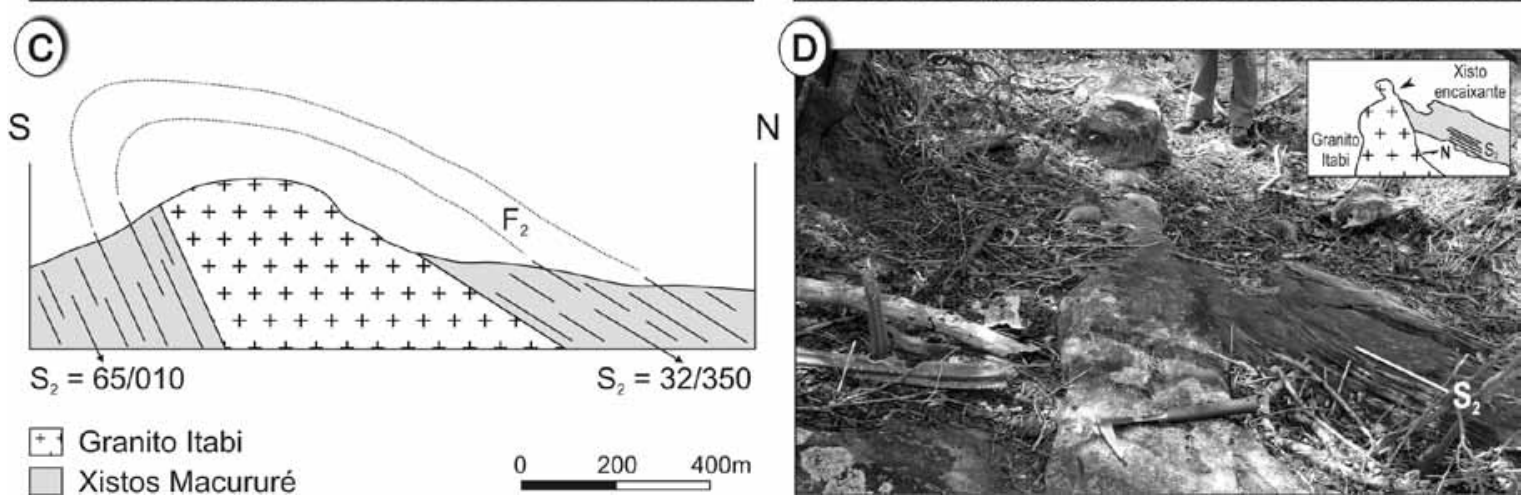

Figura 9 - A. Granito Angico injetado como folhas concordantes à foliação $S_{2}$ do xisto encaixante; B. e C. Granito Angico e Granito Itabi, respectivamente, injetados no plano axial de dobras $F_{2}$; $D$. Granito Itabi sin a tardi-D $D_{2}$ truncando a foliação $S_{2}$ do xisto encaixante.
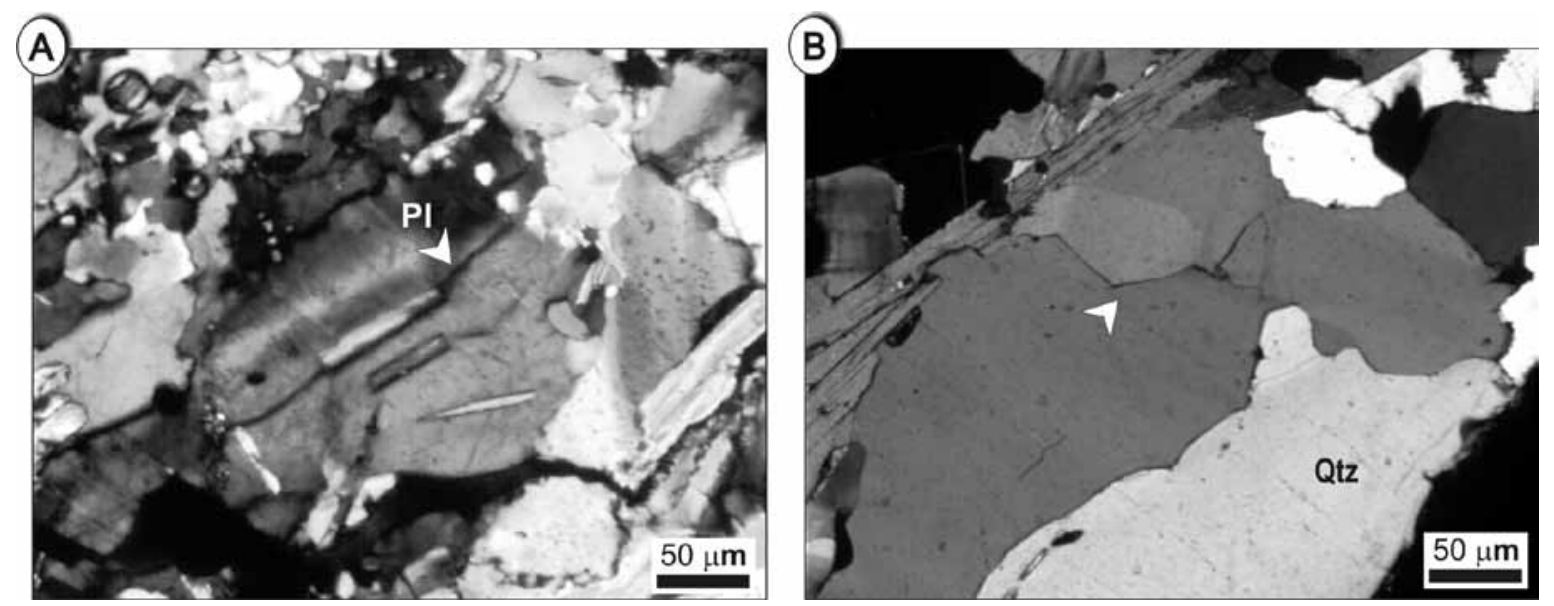

Figura 10 - Aspectos microestruturais dos granitos colisionais. Granito Angico mostrando: A. Migração de borda de grão em plagioclásio; $B$. Grãos de quartzo com contatos de $120^{\circ}$. Pl= plagioclásio, Qtz = quartzo.

DISCUSSÃO E CONCLUSÕES A seqüência de rochas metamórficas que ocorre na EINSL é paraderivada e com fonte siálica, uma vez que contém quartzo, plagioclásio, turmalina, rutilo e zircão, além de paraconglomerados contendo clastos de quartzo e granito. A obliteração das estruturas primárias nas rochas supracrustais é resultado da superposição de sucessivas fases tectono-metamórficas, desenvolvidas durante a oroge- nia neoproterozóica. Tal obliteração dificulta a interpretação, com base em critérios de campo, do ambiente e/ ou ambientes deposicionais dos protólitos sedimentares. No entanto, o xisto inferior conserva localmente estratificação plano-paralela, que sugere depósito turbidítico e rítmico para o mesmo.

$\mathrm{O}$ evento $\mathrm{D}_{1}$ é iniciado com a colisão entre o cráton São Francisco e, provavelmente, o Maciço Per- 
nambuco-Alagoas durante a orogenia brasiliana. Este evento é caracterizado como uma tectônica de nappes que foi responsável pelo empilhamento litológico da EINSL. $\mathrm{D}_{1}$ desenvolve superfícies miloníticas de baixo ângulo $S_{1}$ com mergulho original para $\mathrm{NE}$ e dobras recumbentes, isoclinais a apertadas, e com vergência para SW. $\mathrm{D}_{1}$ gerou uma significativa aloctonia, com transporte tectônico para SW mostrado por indicadores cinemáticos e pela lineação de estiramento $\mathrm{L}_{1}^{\mathrm{X}}$. Neste contexto, a EINSL representa um remanescente de uma destas superfícies de transporte de massa para SW. É provável que a unidade Xistos Inferiores (Fig. 2) seja autóctone e as demais unidades sejam alóctones tendo como base a superfície milonítica que separa esta unidade das demais, a diferença de assinatura magnética da EINSL (alto magnético) e as rochas ao seu entorno (baixo a médio magnético) que pertencem à unidade Xistos Inferiores, e a superficialidade da estrutura. A cristalização de granada e cianita é precoce (cedo a $\sin -\mathrm{D}_{1}$ ) nas unidades acima da unidade Xisto Inferior enquanto que nesta unidade a cristalização destes minerais é tardia $\left(\sin -\mathrm{D}_{2}\right)$. A colocação da porção alóctone sobre a unidade Xisto Inferior poderia ter acionado um cobertor térmico, fazendo com que a associação de minerais metamórficos no Xisto Inferior se desenvolvesse pós- $\mathrm{D}_{1}$. Estes fatos, associados à ocorrência de rochas máfico-ultramáficas metamorfisadas e BIF's, que representam lascas imbricadas nas unidades sedimentares, na base do empurrão, são evidências que comprovam a aloctonia das unidades acima do Xisto Inferior. A superfície de cavalgamento remanescente de $\mathrm{D}_{1}$ pode ter sido alçada para cima do Xisto Inferior pela zona de cisalhamento Belo Monte-Jeremoabo (ZCBMJ, Fig. 1) que é caracterizada como uma zona de cisalhamento transpressiva sinistral (Davison \& Santos 1989). A ZCBMJ ocorre cerca de 10 a $15 \mathrm{~km}$ a N-NE da EINSL, onde ela sofre uma inflexão de E-W para NW-SE (Fig. 1), gerando um maior componente de cavalgamento para SW, compatível com a direção preferencial de transporte para SSW registrada na área da estrutura de interferência. As lascas de rocha máficoultramáficas metamorfisadas alojadas dentro da EINSL poderiam representar lascas de crosta oceânica obductadas nas unidades sedimentares da estrutura durante 0 evento colisional que gerou a Faixa Sergipana, ou seja, poderiam representar restos de ofiolitos. No entanto, o fato destas rochas estarem totalmente metamorfisadas não permitiu, até o momento, que esta hipótese seja confirmada.

No evento $\mathrm{D}_{2}$ uma leve rotação de $\sigma_{1}$ gera dobras assimétricas com vergência para sul e padrões coaxiais em regiões de pouca obliqüidade entre as cinemáticas $\mathrm{D}_{1}$ e $\mathrm{D}_{2}$ (Fig. 6B). Em $\mathrm{D}_{2}$, parte dos empurrões e nappes gerados durante o evento $\mathrm{D}_{1}$ são reaproveitados sendo que o efeito da provável aproximação do Maciço Pernambuco-Alagoas contra o Cráton São Francisco, durante esse evento, produz o empinamento progressivo dos empurrões, resultando em espessamento crustal, acomodado principalmente nas rochas do domínio Macururé e em especial, na área da EINSL.
Durante $\mathrm{D}_{2}$ são gerados vários granitos que cortam as rochas metassedimentares da EINSL (granitos Angico, Areias, Lagoas e Pedra Furada, Fig. 2). O espessamento crustal na área da EINSL durante $\mathrm{D}_{1}$ e $\mathrm{D}_{2}$ pode ter acionado a fusão parcial das rochas metassedimentares gerando dessa forma os magmas progenitores dos granitos colisionais. Os granitos alojados durante $\mathrm{D}_{2}$ podem ser utilizados para delimitar o intervalo de tempo que este evento operou na EINSL e consequentemente no domínio Macururé. Como o evento $\mathrm{D}_{2}$ é o evento colisional de maior expressão na Faixa Sergipana (Jardim de Sá et al. 1986, Araújo et al. 2003), a idade dos granitos da EINSL associados a este evento pode fornecer o intervalo de tempo absoluto mínimo da colisão entre o Cráton São Francisco e o Maciço Pernambuco-Alagoas durante a orogenia brasiliana. $\mathrm{Na}$ área da EINSL existem dois grandes pulsos magmáticos distintos, os granitos pré- $\mathrm{D}_{2}$ e sin a tardi- $\mathrm{D}_{2}$.

O Tonalito Camará é o exemplo de uma intrusão pré-colisional na EINSL, ele registra as estruturas $\mathrm{D}_{2} \mathrm{e}$ é afetado em diferentes graus pelos eventos subseqüentes, não preservando estruturas de fluxo magmático. A sua idade de cristalização de $628 \pm 12$ Ma pode ser utilizada como marcadora da idade máxima para início da deformação $\mathrm{D}_{2}$ na EINSL. Foram obtidas idades U-Pb TIMS em titanita de $584 \pm 10$ Ma para o granito sin- $\mathrm{D}_{2}$ Angico e de $571 \pm 9$ Ma para o granito tardi- $\mathrm{D}_{2}$ Pedra Furada, delimitando, desta forma, mais precisamente o intervalo de duração do evento $\mathrm{D}_{2}$. Utilizando as idades do Tonalito Câmara e do Granito Pedra Furada tem-se aproximadamente 57 milhões de anos de magmatismo associado ao evento $\mathrm{D}_{2}$ operante no domínio Macururé, ou seja, o maior evento de colisão entre o Cráton São Francisco e o Maciço Pernambuco Alagoas durou pelo menos 57 milhões de anos. Este intervalo de tempo é bastante similar às idades dos granitos colisionais e relacionados às zonas de cisalhamentos e ao metamorfismo de alto grau na Província Borborema (Guimarães et al. 2004; Fetter et al., 2003; Silva Filho et al., 2002; Souza et al., 2006; Neves et al., 2006) e em outras faixas orogênicas ao redor do Cráton São Francisco. Heilbron et al. (2004) estimaram um intervalo de tempo de 585-560 Ma para granitos colisionais na Faixa Araçuaí e Mendes et al. (2006) encontraram idades variando de 586 a 584 Ma para três granitos colisionais na Faixa Ribeira. Na Faixa Brasília foram descritos dois episódios de colisão neoproterozóica, um datado em cerca de $794 \mathrm{Ma}$ (Pimentel et al. 1992) e outro em $637 \mathrm{Ma}$ (Valeriano et al. 2004). Portanto, entre 590 e $560 \mathrm{Ma}$ uma grande quantidade de granitos foi alojada em faixas orogênicas ao redor do Cráton São Francisco em resposta a múltiplos eventos colisionais.

O retrabalhamento das estruturas de baixo ângulo $\mathrm{D}_{2}$ pelas zonas de zonas de cisalhamento $\mathrm{D}_{3}$ transpressivas ocorreu após $571 \mathrm{Ma}$, que é a idade do Granito Pedra Furada tardi- $\mathrm{D}_{2}$. A deformação produzida pelo evento $\mathrm{D}_{3}$ gerou uma mega dobra aberta com amplitude de aproximadamente $12 \mathrm{~km}$ e eixo E-W (Fig. 2) que é responsável juntamente com os eventos $\mathrm{D}_{1}+\mathrm{D}_{2}$ pela configuração da EINSL em cogumelo (tipo 2 de Ra- 
msay 1967), que é, desta forma, produto dos eventos $\mathrm{D}_{1}+\mathrm{D}_{2}$ e $\mathrm{D}_{3}$. Durante o evento $\mathrm{D}_{3}$ as foliações $\mathrm{S}_{2}$ e $\mathrm{S}_{3}$ foram significamente empinadas resultado de um forte componente de encurtamento horizontal N-S, possivelmente associado à endentação do Maciço PernambucoAlagoas contra a borda norte do Cráton São Francisco. Brito et al. (2008a e b) obtiveram idades ${ }^{40} \mathrm{Ar}-{ }^{39} \mathrm{Ar}$ no intervalo de 566-551 Ma em biotita de rochas a norte da EINSL e interpretaram estas idades como marcadoras do último evento termal correspondente à deformação dúctil registrada nos lineamentos transcorrentes da Faixa Sergipana como a Zona de Cisalhamento Belo Monte-Jeremoabo.

$\mathrm{O}$ evento $\mathrm{D}_{4}$ encerra a orogenia neoproterozóica na EINSL e é caracterizado pela ocorrência de estruturas rúpteis indicando transição de domínios dúctil-rúptil, já em um nível crustal raso. As estrutu- ras rúpteis encontradas na EINSL são fraturas, falhas normais e falhas transcorrentes dextrais na parte sul da área, que afetam os quartzitos do anel externo da EINSL e juntas extensionais nos granitos (Fig. 2). Os eventos $\mathrm{D}_{3}$ e $\mathrm{D}_{4}$ foram responsáveis pela exumação da EINSL para níveis crustais rasos e responsáveis, portanto, pela atual arquitetura crustal desta área da Faixa Sergipana.

Agradecimentos Os autores agradecem ao suporte financeiro proporcionado pela FAPESP na forma de bolsa de doutorado para JFB (05/60119-5) e auxílio à pesquisa a EPO (02/03085-2), e ao Projeto Milênio do CNPq (42.0222/2005-7). Os comentários de Lena Virgínia Soares Monteiro e de revisor anônimo enriqueceram significativamente este manuscrito e os autores os agradecem muito.

\section{Referências}

Allard G.O. \& Hurst V.J. 1969. Brazil-Gabon geologic link supports continental drift. Science, 163:528-532.

Almeida F.F.M., Brito Neves B.B., Fuck R.A. 1977. Províncias Estruturais Brasileiras. In: SBG, Simpósio de Geologia do Nordeste, 8, Atas, p.363-391.

Almeida F.F.M., Hasui Y., Brito Neves B.B., Fuck R.A. 1981. Brazilian structural provinces: an introduction. Earth Science Review, 17:1-29.

Araújo M.N.C., Oliveira E.P., Carvalho M.J.2003.Endentação na Faixa Sergipana, NE do Brasil: compatibilização entre os elementos estruturais e cinemática. In: SBG, Simpósio Nacional de Estudos Tectônicos, 9, Atas, p.115-117.

Brito Neves B.B., Sial A.N., Albuquerque J.P.T. 1977. Vergência centrífuga residual no Sistema de Dobramentos Sergipanos. Revista Brasileira de Geociências, 7:102114.

Brito R.S.C., Dantas E., Pimentel, M.M., Macambira, M.J.B, Armstrong, R. 2008b. U-Pb, Pb-Pb and Sm-Nd dating for the Southern Alagoas zone- Sergipano belt- basis for the Brazil-Cameroon neoproterozoic correlation. In: South American Symposium on Isotope Geology, 6, 1 CD-Rom.

Brito R.S.C., Vasconcelos P.M., Dantas E.J., Pimentel M.M, Macambira M.J.B.2008a. Ar-Ar dating for the Braziliano orogeny in the Southern Alagoas zone- Sergipano belt. In: South American Symposium on Isotope Geology, 6, Anais, 1 CD-Rom.

Bueno J.F. \& Oliveira. E.P. 2007. Age and structure of syncollisional granites in the Sergipano Belt and implications for the channel flow model. In: SBG, Simpósio Nacional de Estudos Tectônicos, 11, Anais, p.136-138.

Bueno J.F., Oliveira E.P., Araújo M.N.C., Carvalho M.J., McNaughton N. 2005. Granitos e a deformação na Faixa Sergipana: o início da colisão entre o Cráton São Francisco e o Maciço Pernambuco-Alagoas. In: SBG, Simpósio sobre o Cráton São Francisco, 3, Anais, p.192195.

Bueno J.F., Oliveira E.P., McNaughton N., Laux J.H. 2009.
$\mathrm{U}-\mathrm{Pb}$ dating of granites in the Neoproterozoic Sergipano Belt, NE-Brazil, and implications for the timing and duration of continental collision. Gondwana Research, 15: 86-97.

Carvalho M.J. 2005. Evolução tectônica do Domínio Marancó - Poço Redondo: registro das orogêneses Cariris Velhos e Brasiliana na Faixa Sergipana, NE Brasil. Tese de Doutoramento, Instituto de Geociências, Universidade Estadual de Campinas, 175p.

D'el-Rey Silva L.J.H. 1995. Tectonic evolution of the Sergipano Belt, NE Brazil. Revista Brasileira de Geociências, 25:315-332.

D'el-Rey Silva L.J.H. 1999. Basin infilling in the southerncentral part of the Segipano Belt (NE Brazil) and implications for the evolution of Pan-African/Brasiliano cratons and Neoproterozoic sedimentary cover. Journal of South American Earth Sciences, 12:453-470.

da Silva L.C., Pedrosa-Soares A.C., Teixeira L.R., Armstrong R. 2008. Tonian rift-related, A-type continental plutonism in the Aracuai Orogen, eastern Brazil: new evidence for the breakup stage of the Sao FrancisoCongo Paleocontinent. Gondwana Research, 13:527537.

Davison I. \& Santos R.A. 1989. Tectonic Evolution of the Sergipano Fold Belt, NE Brazil, during the Brasiliano Orogeny. Precambrian Research, 45:319-342.

D’el-Rey Silva L.J.H., Dantas E.L., Teixeira J.B.G., Laux J.H., da Silva M.D.G. 2007. U-Pb and Sm-Nd geochronology of amphibolites from the Curaçá Belt, São Francisco Craton, Brazil. Gondwana Research, 12:454-467.

Fetter A.H., Santos T.J.S., Van Schumus W.R., Hackspacher P.C., Brito Neves B.B., Arthaud M.H., Nogueira Neto J.A., Wernick E. 2003. Evidence for Neoproterozoic Continental Arc Magmatism in the Santa Quiteria Batholith of Ceará State, NW Borborerna Province, NE Brazil: Implications for the Assembly of West Gondwana. Gondwana Research, 6:265-273.

Guimarães I.P., Silva Filho A.F., Almeida C.N., Van 
Schumus W.R., Araújo J.M.M., Melo S.C., Melo E.B. 2004. Brasiliano (Pan-African) granitic magmatism in the Pajeú-Paraíba belt, Northeast Brazil: an isotopic and geochronological approach. Precambrian Research, 135:23-53.

Heilbron M., Pedrosa-Soares A., Neto M., da Silva L., Trouw R., Janasi V. 2004. Brasiliano Orogens in Southeast and south Brazil. In: Weinberg R., Trouw R., Fuck R., Hackspacher P. (eds.) The 750-550 Ma Brasiliano Event of South America. Journal of the Virtual Explorer, Electronic Edition, Volume 17, Paper 4. Disponível em: http://virtualexplorer.com.au/article/2004/109/ brasiliano-orogens-in-southeast-and-south-brazil. Acessado em 05/09/2008.

Jardim de Sá E.F., Legrand J.M., Hackspacher P.C. 1981. Contraste de estilos estruturais e metamórficos na Faixa Dobrada Sergipana. Revista Brasileira de Geociências, 11:128-137.

Jardim de Sá E.F., Macedo M.H.E., Fuck R., Kawashita K. 1992. Terrenos proterozóicos na Província Borborema e a margem norte do Cráton São Francisco. Revista Brasileira de Geociências, 22:472-480.

Jardim de Sá E.F., Moraes J.A.C., D’el-Rey Silva L.J.H. 1986. Tectônica tangencial na Faixa Sergipana. In: SBG, Congresso Brasileiro de Geologia, 34, Abstracts, p.1246-1259.

Long L.E., Castellana C.H., Sial A.N. 2005. Age, origin and cooling history of the Coronel João Sá Pluton, Bahia, Brazil. Journal of Petrology, 46:255-273.

McReath I., Lafon J.M., Davison I., Chaves J.M., Conceição H. 1998. Brasiliano-age granitoids in the Sergipana Fold Belt, NE Brazil: the Coronel João Sá Pluton. Journal of South American Earth Science, 11:51-66.

Mendes J.C., Ávila C.A., Pereira R.M., Heilbron M.P.L., Moura C.A.V. 2006. ${ }^{207} \mathrm{~Pb} /{ }^{206} \mathrm{~Pb}$ of zircons from syncollisional I-type granites of the central Ribeira belt, SE Brazil. Gondwana Research, 9:326-336.

Neves S.P., Mariano G., Correia P.B., Silva J.M.R. 2006. 70 m.y. of synorogenic plutonism in eastern Borborema Province (NE Brazil): temporal and kinematic constraints on the Brasiliano Orogeny. Geodinamica Acta, 19: 213236.

Oliveira E.P., Carvalho M.J., Nascimento R.S.,Araújo M.N.C., Dantas E., Basilici G., Bueno J.F., McNaughton N. 2005. Evidence from detrital zircon geochronology and wholerock $\mathrm{Sm}-\mathrm{Nd}$ isotopes for off-craton provenance of clastic metasedimentary units of the Sergipano belt, NE Brazil. In: SBG, Simpósio Nacional de Estudos Tectônicos, 10, Boletim de Resumos Expandidos, p. 308-311.

Oliveira E.P., Toteu S.F., Araújo M.N.C., Carvalho M.J., Nascimento R.S., Bueno J.F., McNaughton N., Basilici G. 2006. Geologic correlation between the Neoproterozoic Sergipano belt (NE Brazil) and the Yaoundé belt (Cameroon, Africa). Journal of African
Earth Science, 44:470-478.

Passchier C.W., Trouw R.A.J. 2005. Microtectonics. Springer, $289 \mathrm{p}$.

Pimentel M.M., Heaman L., Fuck R.A. 1992. Idade do metariolito da seqüência Maratá, Grupo Araxá, Goiás: estudo geocronológico pelos métodos $\mathrm{U}-\mathrm{Pb}$ em zircão. Anais da Academia Brasileira de Ciências, 64:19-28.

Ramsay J.G. 1967. Folding and Fracturing of Rocks. McGraw-Hill, 568 p.

Silva Filho A.F., Guimarães I.P., Lyra de Brito M.F., Pimentel M.M. 1997. Geochemical signatures of main Neoproterozoic late-tectonic granitoids from the Proterozoic Sergipano Belt, Brazil: significance for the Brasiliano Orogeny. International Geology Review, 39:639-659.

Silva Filho A.F., Guimarães I.P., Silva M.M.R. 1992. Utilização de granitóides na definição de domínios tectônicos; aplicação no lado oriental do Sistema de Dobramento Sergipano. In: SBG, Congresso Brasileiro de Geologia, 37, Anais, p.358-359.

Silva Filho A.F., Guimarães I.P., Van Schumus W.R. 2002. Crustal Evolution of the Pernambuco-Alagoas Complex, Borborerna Province, NE Brazil: Nd Isotopic Data from Neoproterozoic Granitoids. Gondwana Research, 5: 409-422.

Silva Filho M.A. 1977. Geologia da Geossinclinal Sergipana $e$ do seu embasamento. Projeto Baixo São Francisco/ Vaza Barris, Relatório Final. Convênio DNPM/CPRM, vol. 1.

Silva J.M.R. 1992. Evolução Tectono-Metamórfica de uma parte da Faixa Sul-Alagoana, Sistema de Dobramentos Sergipano - Nordeste do Brasil. Tese de Doutoramento, Instituto de Geociências, Universidade de São Paulo, $130 \mathrm{p}$.

Silva J.M.R., Campos Neto M.C., Brito Neves B.B. 1995. Deformação e metamorfismo principais de uma parte da Faixa Sul-Alagoana (Complexo Macururé), sistema de dobramentos Sergipano, Nordeste do Brasil. Revista Brasileira de Geociências, 25:343-350.

Souza Z.S., Montel J.M., Gioia S.M.L.C., Hollanda M.H.B.M., Nascimento M.A.L., Jardim de Sá E.F.J., Amaro V.E., Pimentel M.M., Lardeaux J.M., Veschambre M. 2006. Electron microprobe dating of monazite from high-T shear zones in the São José de Campestre Massif, NE Brazil. Gondwana Research, 9:441-445.

Valeriano M.C., Machado N., Simonetti A., Valladares C.S., Seer H. J., Simões L.S.A. 2004. U-Pb geochronology of the southern Brasília belt (SE-Brazil): sedimentary provenance, Neoproterozoic orogeny and assembly of West Gondwana. Precambrian Research, 130:27-55.

ID 12153

Submetido em 05 de setembro de 2008 Aceito em 14 de setembro de 2009 